\title{
EXAFS Peaks and TPR Characterizing Bimetallic Interactions: Effects of Impregnation Methods on the Structure of Pt-Ru/C Catalysts
}

\author{
Nan-Yu Chen, Ming-Chun Liu, Shih-Chieh Yang, and Jen-Ray Chang \\ Department of Chemical Engineering, National Chung Cheng University, Chia-Yi, Taiwan \\ Correspondence should be addressed to Jen-Ray Chang; chmjrc@ccu.edu.tw
}

Received 21 February 2014; Accepted 18 April 2014; Published 13 May 2014

Academic Editor: Jau-Wern Chiou

Copyright (c) 2014 Nan-Yu Chen et al. This is an open access article distributed under the Creative Commons Attribution License, which permits unrestricted use, distribution, and reproduction in any medium, provided the original work is properly cited.

To investigate bimetallic interactions, $\mathrm{Pt}-\mathrm{Ru} / \mathrm{C}$ catalysts were prepared by coimpregnation $\left(\mathrm{Pt}-\mathrm{Ru} \mathrm{co}_{\mathrm{o}} / \mathrm{C}\right)$ and successive impregnation $\left(\mathrm{Ru}-\mathrm{Pt}_{\mathrm{se}} / \mathrm{C}\right)$, while $\mathrm{Pt} / \mathrm{C}, \mathrm{Ru} / \mathrm{C}$, and reduced $\mathrm{Pt}-\mathrm{Ru}_{\text {black }}$ were used as reference. Those samples were characterized by XAS and TPR. When $\mathrm{Pt}_{\text {(absorber) }}-\mathrm{Ru}_{\text {(backscatter) }}$ phase-and-amplitude correction is applied to Fourier transformed (FT) EXAFS of Pt-Rublack at Pt edge, the characteristic peak of Pt-Ru interactions appears at $2.70 \AA \AA$, whereas, when Pt-Pt correction is applied, the peak appears at about $2.5 \AA$. Detailed EXAFS analysis for $\mathrm{Pt}-\mathrm{Ru}_{\mathrm{co}} / \mathrm{C}$ and $\mathrm{Pt}-\mathrm{Ru}_{\mathrm{se}} / \mathrm{C}$ confirms the nature of the characteristic peak and further indicates that the interactions can semiquantitatively be determined by the relative intensity between Pt-Ru and Pt-Pt characteristic peaks. This simple method in determining bimetallic interaction can be extended to characterize Pt-Pd $/ \gamma-\mathrm{Al}_{2} \mathrm{O}_{3}$. However, for Pt$\mathrm{Re} / \gamma-\mathrm{Al}_{2} \mathrm{O}_{3}$, Pt-Re interactions cannot be determined by the method because of the overlap of Pt-Pt and Pt-Re characteristic peaks due to similar phase functions.

\section{Introduction}

It has been reported that the catalytic properties of supported Pt catalysts can be markedly changed by the addition of the second metal $\left(\mathrm{M}_{2 \mathrm{nd}}\right)$; for example, $\mathrm{Ru}$ are known to substantially improve the catalytic performance in the electrochemical oxidation of hydrogen fuels contaminated by carbon monoxide [1-10]; Re and Ir stabilize the Pt catalyst in naphtha reforming reaction; and Pd improves sulfur tolerance level of Pt for catalytic saturation of aromatics in diesel fuel [11-19].

Several explanations have been offered for the role of $M_{2 n d}$ in improving the catalytic performance: (1) it may change the morphology of Pt clusters and help anchor Pt and maintain it in a state of high dispersion [14, 20-26]; (2) it may convert the poisonous species into harmless compound in the reaction $[2,27]$; (3) in bonding with Pt, it may change the electronic properties and geometric features of Pt thereby decreasing the adsorption of poisonous species on $\mathrm{Pt}[18,24$, 28-33]; and (4) in association with Pt, it may modify the catalytic properties of Pt [34-38]. To discriminate the role of $\mathrm{M}_{2 \text { nd }}$ in improving the catalytic performances, it is crucial to determine the structure of the catalysts, specifically, the extent of bimetallic interaction.

TPR (temperature programmed reduction) has been widely used to characterize the bimetallic interactions. For $\mathrm{Ru}-\mathrm{Pt}$ and Re-Pt catalysts, it has been suggested that the TPR characterized by a single peak would indicate a catalytic reduction of $M_{2 n d}$ [39-43]; presumably, $M_{2 n d}$ precursors, which are highly mobile or located nearby $\mathrm{Pt}$, can quickly migrate to the hydrogen-covered Pt where they are catalytically reduced by $\mathrm{Pt}$. This postulate suggests the formation of bimetallic interactions. In contrast, as the $\mathrm{M}_{2 \text { nd }}$ precursors are immobile or located far away from $\mathrm{Pt}$, isolated peaks are observed in TPR spectrum, one for Pt and one for $M_{2 n d}$, which are reduced separately; hence, no $\mathrm{M}_{2 \mathrm{nd}}-\mathrm{Pt}$ interactions were suggested. However, the reduced $\mathrm{M}_{2 \mathrm{nd}}$ with increased mobility could migrate toward $\mathrm{Pt}$, leading to $\mathrm{M}_{2 n d}-\mathrm{Pt}$ interactions. In addition, decomposition of surface functional groups in hydrogen reduction may change diffusion rate 
of spillover hydrogen, the reducibility of $\mathrm{M}_{2 \text { nd }}$, and the metal-support interactions. These factors will be reflected in TPR spectra but normally are not taken into account in interpretation of TPR results. Since catalyst structure plays a crucial role in determining the catalytic properties, TPR is regarded to be insufficient to characterize the catalyst structure and to rationalize the roles of $\mathrm{M}_{2 \mathrm{nd}}$ in improving the catalytic performance.

The main parameter controlling the catalyst morphology was the method of preparation. Bimetallic catalysts can be prepared by a number of synthetic methods, each with its own distinct advantages [26, 39, 44-52]. Among them, impregnation method is the commonest one and is used widely in the preparation of commercial catalysts. By coimpregnation methods, $\mathrm{Pt}$ and $\mathrm{M}_{2 \mathrm{nd}}$ ion precursors collide with each other and intimately get mixed together. Thus the metals could aggregate together in the $\mathrm{N}_{2}$ drying step. Hence, bimetallic interactions are expected upon $\mathrm{H}_{2}$ reduction. In contrast, in the successive impregnation method, Pt ion precursors and $\mathrm{M}_{2 \text { nd }}$ ions would aggregate separately; hence, Pt clusters are expected to be segregated from $\mathrm{M}_{2 \text { nd }}$ clusters with little interactions.

The goal of the research summarized here was to investigate the structure of $\mathrm{Pt}-\mathrm{Ru} / \mathrm{C}$ catalysts prepared by coimpregnation and successive impregnation methods by using in situ extended X-ray absorption fine structure (EXAFS) spectroscopy, which has been proven to be a powerful technique for the characterization of bimetallic catalysts [53, 54]. Since EXAFS contribution of metal-support interactions is crucial in determining the morphology of Ru-Pt clusters that is strongly coupled with metal oxide, $\mathrm{M}\left(\mathrm{Pt}\right.$ or $\left.\mathrm{M}_{2 \mathrm{nd}}\right)$ $\mathrm{O}$ contribution in situ catalyst pretreatment is necessary for preventing the oxidation of metal clusters.

The specific goals of this study were to investigate the characteristic peaks of bimetallic catalysts and determine the bimetallic interactions semiquantitatively by phase-andamplitude function corrected Fourier transform method. In this investigation, $\mathrm{Pt} / \mathrm{C}, \mathrm{Ru} / \mathrm{C}$, and reduced $\mathrm{Pt}-\mathrm{Ru}_{\text {black }}$ were prepared to study the structure for comparison. In developing a simple method to characterize the bimetallic interactions, the correlation between the ratio of Pt-Ru to Pt-Pt characteristic peak intensity $\left(I_{\mathrm{Pt}-\mathrm{Ru}} / I_{\mathrm{Pt}-\mathrm{Pt}}\right)$ and the ratio of Pt$\mathrm{Ru}$ to Pt-Pt coordination number $\left(N_{\mathrm{Pt}-\mathrm{Ru}} / N_{\mathrm{Pt}-\mathrm{Pt}}\right)$ estimated from detailed EXAFS analysis was employed. This method can hopefully be extended to other important commercial bimetallic catalysts, specifically, for Pt-Pd catalysts.

\section{Experimental Methods}

2.1. Sample Preparation. Ru-Pt catalyst samples were prepared by using coimpregnation and successive impregnation, respectively. For the coimpregnation sample $\left(\mathrm{Pt}-\mathrm{Ru}_{\mathrm{co}} / \mathrm{C}\right)$, $5 \mathrm{~g}$ of carbon black powder (Vulcan, XC-72R) was mixed with $33.5 \mathrm{~mL}$ of solution containing $0.660 \mathrm{~g}$ of $\mathrm{H}_{2} \mathrm{PtCl}_{6} \cdot 6 \mathrm{H}_{2} \mathrm{O}$ and $0.625 \mathrm{~g}$ of $\mathrm{RuCl}_{3} \cdot \mathrm{XH}_{2} \mathrm{O}$ (Strem) and evacuated at $10^{-2}$ $10^{-3}$ torr and about $80^{\circ} \mathrm{C}$ for overnight. The catalyst sample contained $4.7 \mathrm{wt} \% \mathrm{Pt}$ and $4.4 \mathrm{wt} \% \mathrm{Ru}$, as measured by inductively plasma optical emission measurement (ICP-OES,
Perkin Elmer PE Optima 4300). For the successive impregnation sample $\left(\mathrm{Pt}-\mathrm{Ru}_{\mathrm{se}} / \mathrm{C}\right), \mathrm{PtO}_{2} / \mathrm{C}$ was first prepared by impregnating carbon black powder with $\mathrm{H}_{2} \mathrm{PtCl}_{6}$, reducing in $\mathrm{H}_{2}$ at $200^{\circ} \mathrm{C}$ for $2 \mathrm{~h}$ and then calcining in air at $200^{\circ} \mathrm{C}$ for $2 \mathrm{~h}$. The resulting $\mathrm{PtO}_{2} / \mathrm{C}$ of $5.0 \mathrm{~g}$ was brought into contact with $0.625 \mathrm{~g}$ of $\mathrm{RuCl}_{3} \cdot \mathrm{XH}_{2} \mathrm{O}$ in $22.0 \mathrm{~mL}$ of doubly distilled deionized water, followed by evacuation at $10^{-2}-10^{-3}$ torr and about $80^{\circ} \mathrm{C}$. The Pt- $\mathrm{Ru}_{\mathrm{se}} / \mathrm{C}$ sample contained $4.4 \mathrm{wt} \% \mathrm{Pt}$ and $4.1 \mathrm{wt} \% \mathrm{Ru}$. For TPR study, Pt/C and $\mathrm{Ru} / \mathrm{C}$ catalysts were prepared by impregnation of carbon black with $\mathrm{H}_{2} \mathrm{PtCl}_{6}$ and $\mathrm{RuCl}_{3}$, respectively, followed by drying at $80^{\circ} \mathrm{C}$.

$\mathrm{Pt}-\mathrm{Pd} / \gamma-\mathrm{Al}_{2} \mathrm{O}_{3}$ catalyst was prepared by successive impregnation method using $\mathrm{H}_{2} \mathrm{PtCl}_{6}$ and $\mathrm{Pd}\left(\mathrm{O}_{2} \mathrm{CCH}_{3}\right)_{2}$ as $\mathrm{Pt}$ and $\mathrm{Pd}$ precursors, respectively, and was denoted as Pt-Pd(OAc) $)_{2} / \gamma-\mathrm{Al}_{2} \mathrm{O}_{3}$. The $\gamma-\mathrm{Al}_{2} \mathrm{O}_{3}$ support was prepared from Versal 250 and capital $\mathrm{B}$ pseudoboehmitic alumina powder. For comparison, $\mathrm{Pt} / \gamma-\mathrm{Al}_{2} \mathrm{O}_{3}$ was prepared by incorporation of $\mathrm{H}_{2} \mathrm{PtCl}_{6}$ into $\gamma-\mathrm{Al}_{2} \mathrm{O}_{3}$ and followed by air calcination at $450^{\circ} \mathrm{C}$ and $\mathrm{Pd}(\mathrm{OAc})_{2} / \gamma-\mathrm{Al}_{2} \mathrm{O}_{3}$ was prepared by impregnating $\mathrm{Pd}\left(\mathrm{O}_{2} \mathrm{CCH}_{3}\right)_{2}$ on $\gamma-\mathrm{Al}_{2} \mathrm{O}_{3}$ without calcination. The details of the preparation procedure were shown in our previous paper [55]. Pt-Re $/ \gamma-\mathrm{Al}_{2} \mathrm{O}_{3(\mathrm{~d})}$ catalyst was prepared by successive incipit wetness impregnation technique. The $\gamma-\mathrm{Al}_{2} \mathrm{O}_{3}$ (Degussa, aluminum oxide $\mathrm{C}$ ) was first brought in contact with a solution of $\mathrm{Pt}\left(\mathrm{NH}_{3}\right)_{4}\left(\mathrm{NO}_{3}\right)_{2}$ (Strem) in deionized water, followed by drying at $120^{\circ} \mathrm{C}$ overnight. The sample was then brought in contact with a solution of $\mathrm{NH}_{4}\left(\mathrm{ReO}_{4}\right)$ (Alfa), dried at $120^{\circ} \mathrm{C}$ for $12 \mathrm{~h}$, and calcined at $500^{\circ} \mathrm{C}$ for $4 \mathrm{~h}[19]$. The catalyst sample contained $0.47 \mathrm{wt} \% \mathrm{Pt}$ and $0.69 \mathrm{wt} \%$ Re (determined by inductively plasma optical emission spectroscopy using a Janell-Ash 1100 instrument) and was stored in a glove box before EXAFS measurement.

2.2. Temperature-Programmed Reduction. The apparatus used for the temperature-programmed reduction (TPR) has been described by McNicol [56]. The experiments were performed with $\mathrm{H}_{2}$ : Ar mixture (10:90 molar) flowing at about $30 \mathrm{~mL}(\mathrm{NTP}) / \mathrm{min}$ at $1 \mathrm{~atm}$. After $012 \mathrm{~g}$ of the catalyst sample was charged into a quartz TPR cell, gas stream was passed through the catalyst sample. When the thermal conductivity detector (TCD) signal became stable, the sample was heated at $10^{\circ} \mathrm{C} / \mathrm{min}$ to $700^{\circ} \mathrm{C}$ by a temperatureprogrammed furnace. The reduction temperature was monitored with a K-type thermocouple and the water produced by reduction was trapped into a column of silica gel. The output polarity was set so that positive TCD signals indicate hydrogen consumption.

2.3. X-Ray Absorption Spectroscopy. The EXAFS experiments with $\mathrm{Pt}-\mathrm{Ru} / \mathrm{C}$ and $\mathrm{Pt}-\mathrm{Pd} / \gamma-\mathrm{Al}_{2} \mathrm{O}_{3}$ at $\mathrm{Pt} \mathrm{L}_{\mathrm{III}}$-edge were performed on X-ray beam line BL17C1 of National Synchrotron Radiation Research Center (NSRRC) in Hsinchu, Taiwan, while those samples at $\mathrm{Ru}$ and Pd $\mathrm{K}$ edge were measured on the superconducting wavelength shifter beam line $01 \mathrm{C}$, with energy ranging from 5 to $33 \mathrm{keV}$. The Pt-Re $/ \gamma-\mathrm{Al}_{2} \mathrm{O}_{3(\mathrm{~d})}$ sample was measured on X-ray beam line X-11A at National Synchrotron Light Source at Brookhaven National Laboratory, Upton, Long Island, New York. Before EXAFS measurement, 
the samples were predried in flowing He for $1 \mathrm{~h}$ and then reduced in situ with flowing $\mathrm{H}_{2}$ at $450^{\circ} \mathrm{C}$ for $4 \mathrm{~h}$.

The electron storage ring of NSRRC was operated at an energy level of $1.5 \mathrm{GeV}$ and a beam current of $360 \mathrm{~mA}$. A $\mathrm{Si}(111)$ double-crystal monochromator was used for energy selection, and two Rh-coated mirrors (mainly for the purpose of collimating and focusing the synchrotron beam) are used to eliminate high energy photons. The transmission measurement geometry was arranged using gas-filled ionization chambers to monitor the intensities of the incident and transmitted X-rays and standard $\mathrm{Pt}, \mathrm{Pd}$ foil, and $\mathrm{Ru}_{\text {black }}$ were simultaneously measured as a reference so that energy calibration could be done between scans.

The Pt-Ru catalyst samples were pressed into a selfsupporting wafer and placed into a controlled-atmosphere EXAFS cell. In flowing $50 \mathrm{~mL} / \mathrm{min}$ purified, dried grade $5 \mathrm{H}_{2}$ at atmospheric pressure, they were heated at a rate of $5^{\circ} \mathrm{C} / \mathrm{min}$ to $300^{\circ} \mathrm{C}$ and held at that temperature for $1 \mathrm{~h}$. After the cell was cooled to room temperature, the EXAFS measurements were made in energy from $200 \mathrm{eV}$ below the platinum $\mathrm{L}_{\text {III }}$ absorption edge $(11564 \mathrm{eV})$ and ruthenium $\mathrm{K}$ edge $(22117 \mathrm{eV})$, respectively, to $1200 \mathrm{eV}$ above the edge. EXAFS measurements were also made with reference material, $\mathrm{Pt}-\mathrm{Ru}_{\text {black }}$ (Alfa Aesar). The Pt- $\mathrm{Ru}_{\text {black }}$ sample was loaded into the EXAFS cell, reduced with $\mathrm{H}_{2} 300^{\circ} \mathrm{C}$ for $1 \mathrm{~h}$; the sample was noted as $\mathrm{Pt}-\mathrm{Ru}_{\text {black }}$. After the sample was cooled to room temperature, the measurement was performed in $\mathrm{H}_{2}$ environment. The EXAFS measurement procedure for $\mathrm{Pt}-\mathrm{Pd} / \gamma-\mathrm{Al}_{2} \mathrm{O}_{3}, \mathrm{Pt} / \gamma-\mathrm{Al}_{2} \mathrm{O}_{3}$, and $\mathrm{Pt}-\mathrm{Pd} / \gamma-\mathrm{Al}_{2} \mathrm{O}_{3}$ is the same as that for Pt-Ru catalyst samples except that these samples $\left(\mathrm{PtO}_{2} / \gamma-\mathrm{Al}_{2} \mathrm{O}_{3}, \mathrm{Pd}(\mathrm{OAc})_{2} / \gamma-\mathrm{Al}_{2} \mathrm{O}_{3}\right.$, and $\mathrm{PtO}_{2}-\mathrm{Pd}(\mathrm{OAc})_{2} / \gamma-$ $\mathrm{Al}_{2} \mathrm{O}_{3}$ ) were reduced ex situ at $450^{\circ} \mathrm{C}$ under the 580 psig of pure hydrogen for $6 \mathrm{~h}$.

Data reduction and data analysis were performed with the XDAP code developed by Vaarkamp et al. [57]. Standard procedures were followed to extract the EXAFS data from the measured absorption spectra. The preedge was approximated by a modified Victoreen curve [58] and the postedge background was subtracted using cubic spline routines $[59,60]$. Normalization was performed by dividing the backgroundsubtracted spectrum by the height at $50 \mathrm{eV}$ above the edge $[57,61]$. Phase shifts and backscattering amplitudes functions of Pt-Ru, Ru-Pt, Pt-Pd, Pd-Pt, Pt-O, Pt-Cl, Ru-O, Ru-Cl, and $\mathrm{Pd}-\mathrm{O}$ were generated by FEFF8 code [62] and used as reference files for EXAFS data analysis.

\section{Results and Discussion}

3.1. TPR Characterizing $P t / C, R u / C$, and $P t-R u / C$ Catalysts. As shown in Figure 1, the maximum reduction rate of single metallic $\mathrm{Pt} / \mathrm{C}$ occurs at $180^{\circ} \mathrm{C}$ and that of the $\mathrm{Ru} / \mathrm{C}$ catalyst is at $250^{\circ} \mathrm{C}$ with a shoulder at $230^{\circ} \mathrm{C}$. For the bimetallic catalysts, two characteristic peaks at 175 and $255^{\circ} \mathrm{C}$ were observed for $\mathrm{Pt}-\mathrm{Ru}_{\mathrm{se}} / \mathrm{C}$ whereas the $\mathrm{Pt}-\mathrm{Ru}_{\mathrm{co}} / \mathrm{C}$ catalysts are characterized by a single broad peak peaking at $200^{\circ} \mathrm{C}$.

Inferred from the mechanism for the platinum-catalyzed rhenium reduction in $\mathrm{Pt}-\mathrm{Re} / \gamma-\mathrm{Al}_{2} \mathrm{O}_{3}[39,63]$, the TPR spectra characterized by a single peak of the $\mathrm{Pt}-\mathrm{Ru}_{\mathrm{co}} / \mathrm{C}$ suggest

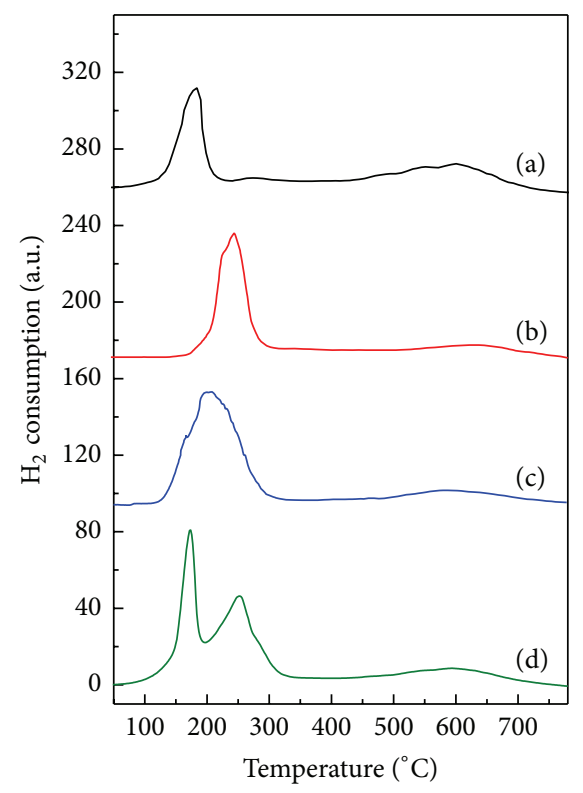

Figure 1: TPR profiles for (a) Pt/C, (b) Ru/C, (c) Pt-Ru $\mathrm{Ru}_{\mathrm{co}} / \mathrm{C}$, and (d) $\mathrm{Pt}-\mathrm{Ru}_{\mathrm{se}} / \mathrm{C}$.

the formation of Pt-Ru bimetallic interactions, possibly, due to the close proximity of the $\mathrm{Pt}$ and $\mathrm{Ru}$ in the coimpregnation method.

Two separated TPR characteristic peaks being observed for $\mathrm{Pt}-\mathrm{Ru}_{\mathrm{se}} / \mathrm{C}$ would suggest that $\mathrm{Pt}$ and $\mathrm{Ru}$ clusters are segregated, with little or no bimetallic interaction $[39,63]$. Since TPR is unable to determine the existence of bimetallic interaction conclusively, EXAFS was used as an alternative to examine the extent of the bimetallic interaction.

3.2. EXAFS Characteristic Peaks of Ru-Pt Bimetallic Interaction. A general expression for EXAFS function is formulated as follows:

$$
x(k)=\sum_{j=1}^{n}\left(A_{j}(k) \sin \left(2 k R_{j}+\emptyset_{j}(k)\right)\right) .
$$

The EXAFS function is a superposition of contributions from $j$ different sine function coordination shell modulated by an amplitude function $A_{j}(k)$. In the argument of sine function, $R_{j}$ is the average distance between the absorbing atom and the neighboring atoms in $j$ coordination shell and $\phi_{j}(k)$ is a phase shift function and is approximated by linear dependence on $k$; that is, $\phi_{j}(k)=\phi_{j}^{0}+\sigma_{j} * k$. In order to separate the contributions from different shells, Fourier transform is performed to the EXAFS function and is formulated as

$$
\theta_{n}(r)=\frac{1}{(2 \pi)^{1 / 2}} \int_{k_{\min }}^{k_{\max }} k^{n} x(k) e^{2 i k r} d k .
$$

The resulting Fourier transformed function will give maxima at the radii that are related to the coordination distance $R_{j}$ in (1). However, due to the presence of phase function, the Fourier transformed EXAFS function peaks 


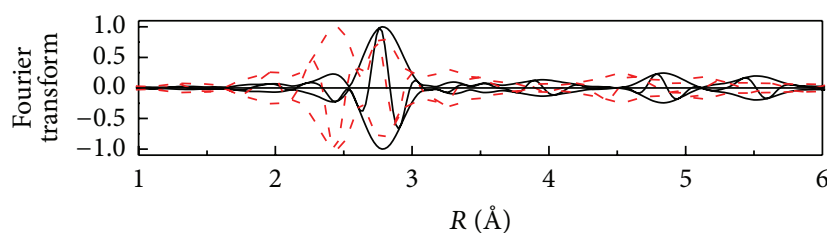

(a)

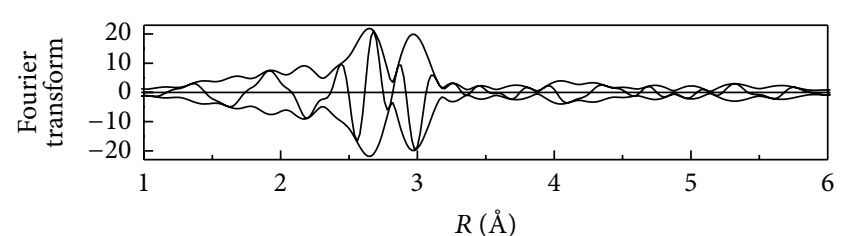

(b)

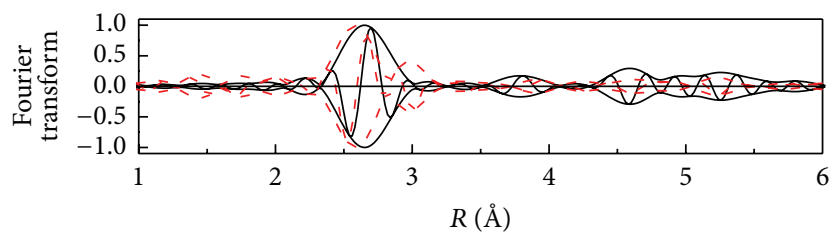

(c)

Figure 2: Comparison of the normalized imaginary and magnitude of Fourier transfom (a) ( $k^{3}$-weighted, $3.0<k<18 \AA^{-1}$, Pt-Pt phase and amplitude corrected) of EXAFS data at Pt $\mathrm{L}_{\mathrm{III}}$ edge for Pt foil (black line) and Pt-Ru black $\left(\right.$ red line), (b) $\left(k^{3}\right.$-weighted, $3.0<k<18 \AA^{-1}$, $\mathrm{Pt}$-Ru phase and amplitude corrected) of EXAFS data at $\mathrm{Pt}_{\mathrm{III}}$ edge for $\mathrm{Pt}$ - $\mathrm{Ru}_{\text {black }}$, and (c) $\left(k^{3}\right.$-weighted, $3.0<k<18 \AA^{-1}$, Ru-Ru phase and amplitude corrected) of EXAFS data at $\mathrm{Ru} \mathrm{K}$ edge for $\mathrm{Ru}$ foil (black line) and $\mathrm{Pt}-\mathrm{Ru}_{\text {black }}$ (red line).

at a distance of $R+\sigma / 2$, instead of $R$. Moreover, due to the influence of the nonlinear amplitude function, specifically, for an absorber-backscatter pair containing high- $Z$ backscatter atom, more than one peak will be present for a single shell. These two factors complicate the study of bimetallic interactions by normal Fourier transform (2). In order to eliminate the complication, the Fourier transform is corrected by replacing $\chi(k)$ with $\chi(k) e^{-i \phi(k)} / F(k)$ and the corrected Fourier transform is formulated as

$$
\theta_{n}^{c}(r)=\frac{1}{(2 \pi)^{1 / 2}} \int_{k_{\min }}^{k_{\max }} x(k) \frac{e^{-i \phi(k)}}{F(k)} k^{n} e^{2 i k r} d k .
$$

By this correction, only one peak will appear for an absorber-backscatter pair and the faulty coordination distance can also be corrected. Hence, for an absorberbackscattering pair $X-Y$, if right phase and amplitude function is applied, the imaginary part of the Fourier transformed EXAFS function will peak positively and center at the maximum of the magnitude; the correct coordination distance can thus be determined by the peak location [60, 64-66]. With the help of phase and amplitude phase functions calculated from FEFF and the phase-and-amplitude corrected Fourier transform, different type of neighbors can be identified by different phase and/or amplitude correction. However, for bimetallic catalysts, the coexistence of two absorberbackscattering pairs complicates the phase-and-amplitude correction due to the difference in phase and amplitude function for different backscattering metals. For instance, when Pt-Pt phase-and-amplitude correction that was applied to EXAFS function involved both $\mathrm{Pt}-\mathrm{Ru}$ and $\mathrm{Pt}-\mathrm{Pt}$ pairs, the coordination distance of Pt-Pt will be correct, whereas the distance for Pt-Ru deviates from real distance of about $\left(\sigma_{\mathrm{Pt}-\mathrm{Pt}}-\sigma_{\mathrm{Pt}-\mathrm{Ru}}\right) / 2$.

In order to identify the neighboring atom of $\mathrm{Pt}$, a $k^{3}$-weighted Pt-Pt phase-and-amplitude corrected Fourier transform in the range of $3.0<k<18.0 \AA^{-1}$ was performed to the EXAFS functions characterizing Pt-R $\mathrm{u}_{\text {black }}$ and $\mathrm{Pt}$ foil at $\mathrm{Pt}$ edge. As shown in Figure 2, a positive peak at about $2.75 \AA$ appears in the imaginary part of the normalized Fourier transformed EXAFS for Pt- $\mathrm{Ru}_{\text {black }}$ and Pt foil (Figure 2(a)), while a negative peak at about $2.5 \AA$ was only observed for $\mathrm{Pt}-\mathrm{Ru}_{\text {black }}$. For $\mathrm{Pt}-\mathrm{Ru}_{\text {black }}$, the positive peak coincides with that for $\mathrm{Pt}$ foil and was assigned as the Pt-Pt characteristic peak. Thus the negative peak was assigned as $\mathrm{Pt}-\mathrm{Ru}$ characteristic peak. Due to an approximate $\pi$ radian difference between $\mathrm{Pt}-\mathrm{Pt}$ and $\mathrm{Pt}-\mathrm{Ru}$ phase function $\left(\phi_{\mathrm{Pt}-\mathrm{Pt}}{ }^{0}-\phi_{\mathrm{Pt}-\mathrm{Ru}}{ }^{0}\right)$, Pt-Ru contribution corrected by Pt-Pt phase function results in a negative peak. Another small peak appearing at about $3.2 \AA$ was also contributed from Pt$\mathrm{Ru}$ (Figure 2(a)); as mentioned in the preceding paragraphs, isolated Pt-Ru shell obtained from detailed EXAFS analysis (Figure 3(a)) confirmed the assignment. In order to confirm the assignments and to estimate the coordination distance of $\mathrm{Pt}-\mathrm{Ru}, \mathrm{Pt}-\mathrm{Ru}$ phase-and-amplitude correction was applied to EXAFS function of $\mathrm{Pt}-\mathrm{Ru}_{\text {black }}$. As expected, a positive and a negative peak appears at about $2.7 \AA$ and $3.0 \AA$, respectively (Figure 2(b)). The positive peak is contributed from Pt-Ru. Again, due to the difference in the phase shift function between Pt-Pt and Pt-Ru, the characteristic peak of Pt-Pt shown in Figure 2(b) is negative and longer than that shown in Figure 2(a).

Similar to the Pt edge analysis, application of Ru-Ru phase and amplitude corrected to Fourier transformed EXAFS functions at $\mathrm{Ru}$ edge for $\mathrm{Pt}-\mathrm{Ru}_{\text {black }}$ and $\mathrm{Ru}_{\text {black }}$ results in a positive peak for both samples and an additional negative peak for $\mathrm{Pt}-\mathrm{Ru}_{\text {black }}$ (Figure 2(c)). The negative peak was thus assigned as the characteristic peak of Ru-Pt.

For detailed analysis of EXAFS characterizing $\mathrm{Pt}-\mathrm{Ru}_{\text {black }}$ at Pt edge, 1st shell Pt-Pt and Pt-Ru contributions were isolated by Fourier filter $\left(0.607<R<3.307 \AA\right.$ and $3.0<k^{2}<$ $\left.16.0 \AA^{-1}\right)$. At the beginning, the coarse structural parameters for $\mathrm{Pt}-\mathrm{Pt}$ contribution were determined by adjusting the 


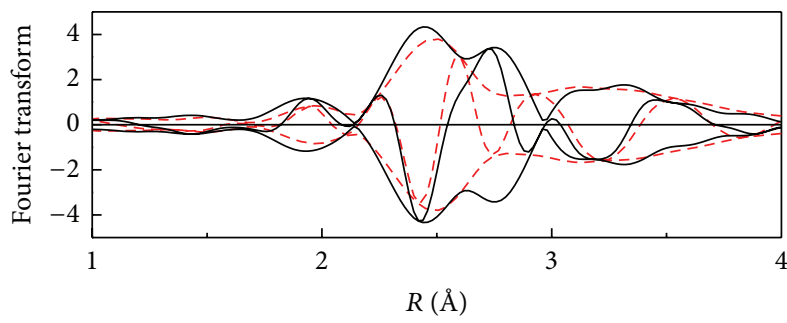

(a)

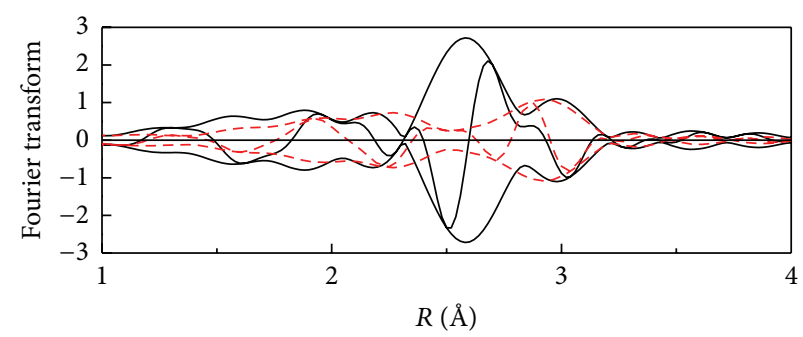

(b)

FIgURE 3: Illustration of (a) Pt-Ru contribution for Pt-Rublack : imaginary part and magnitude of Fourier transform $\left(k^{2}\right.$-weighted, $3.0<k<$ $16 \AA^{-1}$, Pt-Pt phase and amplitude corrected) for raw data at Pt $\mathrm{L}_{\mathrm{III}}$ edge minus calculated Pt-Pt (red line) and raw data (black line) and (b) $\mathrm{Ru}$-Pt contribution for Pt- $\mathrm{Ru}_{\text {black}}$ : imaginary part and magnitude of Fourier transform $\left(k^{2}\right.$-weighted, $3.0<k<16 \AA^{-1}$, Ru-Ru phase and amplitude corrected) for raw data at Ru K edge minus calculated Ru-Ru (red line) and raw data (black line).

parameters to give the best agreement with the Pt-Pt characteristic peak of the Fourier-isolated EXAFS function (raw data). An EXAFS function calculated from the parameters for Pt-Pt contribution was then subtracted from the raw data. As expected, a symmetric peak appeared at about $2.7 \AA$ after applying Pt-Ru phase-and-amplitude Fourier transform to the difference EXAFS data. The structural parameters for Pt$\mathrm{Ru}$ contribution were then estimated by a single-shell fitting routine. More accurate parameters for $\mathrm{Pt}-\mathrm{Pt}$ contribution were then estimated by fitting the difference data obtained from the subtraction of the calculated Pt-Ru contribution from the raw data. Further refinement of the analysis was done by the use of multishell fitting routine with the initial guesses obtained from single-shell fitting routine $[67,68]$.

Detailed analysis of EXAFS characterizing $\mathrm{Pt}-\mathrm{Ru}_{\text {black }}$ at $\mathrm{Ru}$ edge is similar to that described for the Pt edge. The EXAFS data were Fourier-transformed over the useful range $\left(3.0<k^{2}<16.0 \AA^{-1}\right)$ and the major contributions, Ru-Ru and $\mathrm{Ru}-\mathrm{Pt}$, were isolated by inverse Fourier transform in the range of $0.6<R<3.012 \AA$. The coarse structural parameters for $\mathrm{Ru}-\mathrm{Ru}$ contribution were determined by fitting $\mathrm{Ru}-\mathrm{Ru}$ characteristic peak, manually. The values of these parameters were fixed and then the difference file technique and singleshell fitting routine were applied to estimate the parameters for Ru-Pt. The contribution of $\mathrm{Ru}-\mathrm{Pt}$ was subtracted from raw data and the improved parameters for $\mathrm{Ru}-\mathrm{Ru}$ were then estimated by fitting the difference data. The recursive iterations were carried out until a satisfactory overall fit was reached.

As a criterion of the satisfactory overall fit, the distance and Debye-Waller factor characteristics of Ru-Pt interactions determined at Ru edge should be the same as those of the Pt$\mathrm{Ru}$ interactions determined at Pt edge. The comparison of the parameters obtained at two edges is useful for determining the goodness of overall fit. Since the effects of $N$ and $\Delta \sigma^{2}$ and $R$ and $\Delta E_{0}$ on the calculated EXAFS are highly correlated and the contributions of $\mathrm{Ru}-\mathrm{Pt}$ and $\mathrm{Ru}-\mathrm{Ru}$ are strongly coupled, without any constraints in overall fit, the difference of the calculated $\Delta \sigma^{2}$ between $\mathrm{Pt}-\mathrm{Ru}$ and $\mathrm{Ru}-\mathrm{Pt}$ contributions for $\mathrm{Pt}-\mathrm{Ru} / \mathrm{C}$ could be higher than $30 \%$. Hence, $\Delta \sigma^{2}$ value for Ru$\mathrm{Pt}$ was tuned in the fitting process, until $\Delta \sigma^{2}$ value for Pt-Ru is the same as that for the $\mathrm{Ru}-\mathrm{Pt}$ (within standard deviation) reached in parameter estimation. The results of the detailed EXAFS analysis are shown in Table 1 and the illustration of $\mathrm{Pt}-\mathrm{Ru}$ and $\mathrm{Ru}-\mathrm{Pt}$ characteristic peaks was shown in Figure 3.

\subsection{Effects of Preparation Methods on Pt-Ru Bimetallic Inter-} actions. A comparison of Pt-Pt phase-and-amplitude corrected Fourier transform of the EXAFS data at Pt edge representing $\mathrm{Pt}-\mathrm{Ru}_{\text {black }}, \mathrm{Pt}-\mathrm{Ru}_{\mathrm{co}} / \mathrm{C}, \mathrm{Pt}-\mathrm{Ru}_{\mathrm{se}} / \mathrm{C}$, and $\mathrm{Pt} / \mathrm{C}$ is shown in Figure 4(a). For all these samples except $\mathrm{Pt} / \mathrm{C}$, the appearance of the peak at $2.5 \AA$ is the characteristic peak of Pt$\mathrm{Ru}$, suggesting the presence of $\mathrm{Pt}-\mathrm{Ru}$ bimetallic interactions for all Pt-Ru samples. EXAFS evidence of the formation of bimetallic interaction for all $\mathrm{Pt}-\mathrm{Ru}_{\mathrm{se}} / \mathrm{C}$ indicates that a bimetallic catalyst with separated peaks in TPR spectrum still presents bimetallic interactions.

The higher intensity of the peak for $\mathrm{Pt}-\mathrm{Ru}_{\mathrm{co}} / \mathrm{C}$ with respect to that for $\mathrm{Pt}-\mathrm{Ru}_{\mathrm{se}} / \mathrm{C}$ demonstrates that $\mathrm{Pt}-\mathrm{Ru}$ bimetallic interactions can be manipulated by impregnation method and the sample prepared by coimpregnation method leads to stronger bimetallic interactions. The statement is consistent with EXAFS data at $\mathrm{Ru}$ edge. As shown in Figure 4(b), a comparison of $\mathrm{Ru}-\mathrm{Ru}$ phase-and-amplitude corrected Fourier transformed EXAFS data for $\mathrm{Pt}-\mathrm{Ru}_{\text {black}}$, $\mathrm{Pt}-\mathrm{Ru}_{\mathrm{co}} / \mathrm{C}$, and $\mathrm{Pt}-\mathrm{Ru}_{\mathrm{se}} / \mathrm{C}$ shows the presence of $\mathrm{Ru}-\mathrm{Pt}$ characteristic peak and the peak intensity is in the order Pt$\mathrm{Ru}_{\text {black }}>\mathrm{Ru}-\mathrm{Pt}_{c o} / \mathrm{C}>\mathrm{Ru}-\mathrm{Pt}_{\mathrm{se}} / \mathrm{C}$.

The EXAFS data for $\mathrm{Pt}-\mathrm{Ru}_{\mathrm{co}} / \mathrm{C}$ and $\mathrm{Pt}-\mathrm{Ru}_{\mathrm{se}} / \mathrm{C}$ were analyzed by a method slightly different from that described for $\mathrm{Pt}-\mathrm{Ru}_{\text {black }}$ to take care of the metal-carbon interactions. For EXAFS data at Pt edge, after isolating the major contributions of EXAFS data, structural parameters for Pt-Pt and Pt-Ru contributions were estimated by fitting the raw data in the high- $k$ range $\left(7.5<k<16 \AA^{-1}\right)$ by adopting the structural parameters for $\mathrm{Pt}-\mathrm{Ru}_{\text {black }}$ as the initial guesses; contributions from metal-carbon interactions (Pt-C) in this region are small. An EXAFS function calculated with the estimated parameters was then subtracted from the raw data $(3.0<$ $\left.k<16 \AA^{-1}\right)$. The residual spectrum was expected to be contributed from Pt-C or Pt-Cl. For Pt- $\mathrm{Ru}_{\mathrm{se}} / \mathrm{C}$, as expected, after Pt-C phase corrected Fourier transform was performed 
TAble 1: Summary of EXAFS analysis results for Pt-Ru catalysts at $\mathrm{Pt}_{\mathrm{LIII}}$ edge.

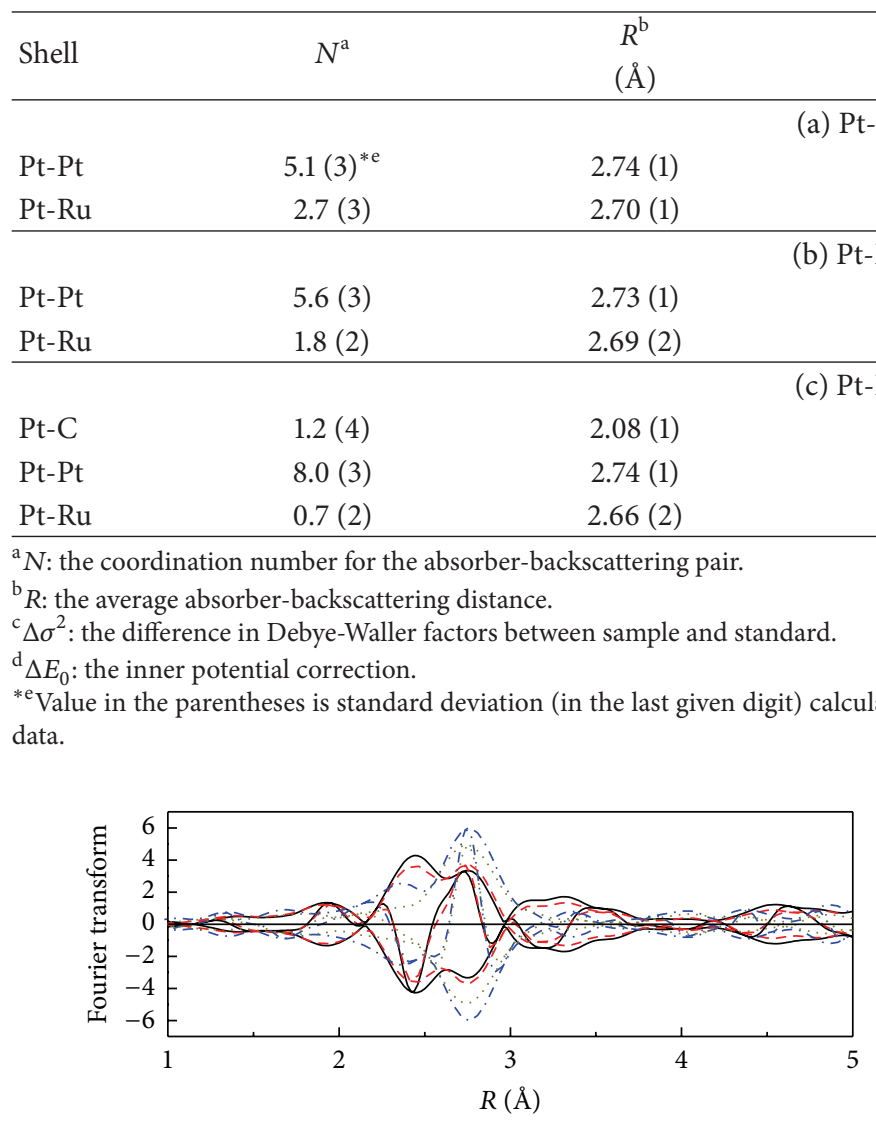

(a)

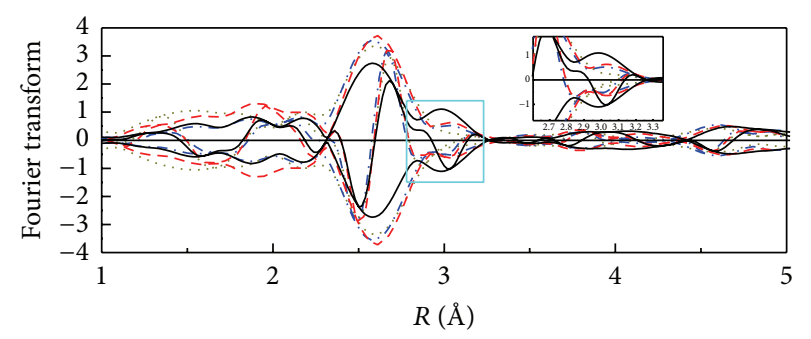

(b)

FIGURE 4: (a) Imaginary part and magnitude of Fourier transform $\left(k^{2}\right.$-weighted, $3.0<k<16 \AA^{-1}$, Pt-Pt phase and amplitude corrected) of EXAFS data at $\mathrm{Pt}_{\mathrm{III}}$ edge for $\mathrm{Pt}-\mathrm{Ru}_{\text {black }}$ (black line), $\mathrm{Pt}-\mathrm{Ru}_{\mathrm{co}} / \mathrm{C}$ (red line), $\mathrm{Pt}-\mathrm{Ru}_{\mathrm{se}} / \mathrm{C}$ (blue line), and $\mathrm{Pt} / \mathrm{C}$ (dark yellow line). (b) Imaginary part and magnitude of Fourier transform $\left(k^{2}\right.$-weighted, $3.0<k<14 \AA^{-1}$, Ru-Ru phase and amplitude corrected) of EXAFS data at Ru K edge for $\mathrm{Pt}-\mathrm{Ru}_{\text {black }}$ (black line), $\mathrm{Pt}-\mathrm{Ru}_{\mathrm{co}} / \mathrm{C}$ (red line), $\mathrm{Pt}-\mathrm{Ru}_{\mathrm{se}} / \mathrm{C}$ (blue line), and $\mathrm{Ru} / \mathrm{C}$ (dark yellow line).

on the difference EXAFS function, a significant peak was detected at about $2.1 \AA$ (Figure 5(a)). The first guess structural parameters for Pt-C were estimated by single-shell fitting routine and more accurate parameters for $\mathrm{Pt}-\mathrm{Pt}, \mathrm{Pt}-\mathrm{Ru}$, and $\mathrm{Pt}-\mathrm{C}$ contributions were determined by fitting the raw data with 12 adjustable parameters; the initial guesses for Pt-Pt and $\mathrm{Pt}-\mathrm{Ru}$ were estimated from raw data in the high $-k$ range $\left(7.5<k<16 \AA^{-1}\right)$.

In contrast to $\mathrm{Pt}-\mathrm{Ru}_{\mathrm{se}} / \mathrm{C}$, after Pt-C phase corrected Fourier transform was performed on the residual EXAFS, no significant peaks were observed in the range $1.0<$ $R<3.0 \AA$ for $\mathrm{Pt}-\mathrm{Ru}_{\mathrm{co}} / \mathrm{C}$ (Figure 5(a)). Pt- $\mathrm{Ru}_{\mathrm{co}} / \mathrm{C}$ had Pt-Pt coordination number of 5.0 suggesting the formation of small $\mathrm{Pt}$ cluster size. Unless bilayer Pt-Ru clusters with Pt layer on the top [69] were formed on the carbon, Pt-C contribution should be observed in the residual spectrum for $\mathrm{Pt}-\mathrm{Ru}_{\mathrm{co}} / \mathrm{C}$. In the model, oxophilic $\mathrm{Ru}$ in a low positive oxidation state interacts with carbon support, stabilizing the dispersion of the Pt clusters.
EXAFS data at Ru edge were analyzed by a method similar to that described for the Pt edge. After the subtraction of $\mathrm{Ru}-\mathrm{Ru}$ and $\mathrm{Ru}-\mathrm{Pt}$ contributions from raw data of $\mathrm{Pt}-\mathrm{Ru}_{\mathrm{co}} / \mathrm{C}$ and $\mathrm{Pt}-\mathrm{Ru}_{\mathrm{se}} / \mathrm{C}$, respectively, $\mathrm{Ru}-\mathrm{Cl}$ phase corrected Fourier transform was applied to the resulting difference files. For $\mathrm{Pt}-\mathrm{Ru}_{\mathrm{co}} / \mathrm{C}$, the appearance of a symmetrical peak at about $2.35 \AA$ in the imaginary part suggests that the chloride ligands have not been removed completely, while the appearance of another peak at about $3.3 \AA$ could be contributed from $\mathrm{Ru}-\mathrm{O}^{*}$ (where $\mathrm{O}^{*}$ denotes the oxygen of oxygen containing functional groups on the carbon surface) (Figure 5(b)). The results suggest that $\mathrm{Pt}-\mathrm{Ru}$ clusters could bond with the functional groups via chloride ligands. For $\mathrm{Pt}-\mathrm{Ru}_{\mathrm{co}} / \mathrm{C}$, the appearance of an asymmetrical peak in the imaginary part suggests the formation of $\mathrm{Ru}-\mathrm{C}$ contribution besides $\mathrm{Ru}-\mathrm{Cl}$, whereas the peak is too small to be analyzed by multishell fitting routine.

The structural parameters for the residual chloride ligands $(\mathrm{Ru}-\mathrm{Cl})$ and $\mathrm{Ru}$-support interactions $(\mathrm{Ru}-\mathrm{C}$ or $\mathrm{Ru}-$ $\left.\mathrm{O}^{*}\right)[70,71]$ were estimated by multishell fitting routine. 


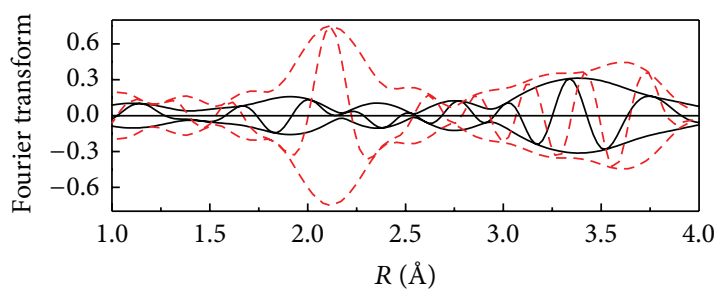

(a)

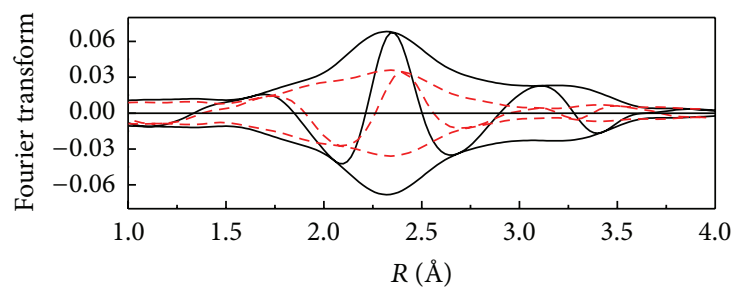

(b)

FIGURE 5: Illustration of the EXAFS contributions characterizing the metal-carbon interactions. (a) Imaginary part and magnitude of Fourier transform $\left(k^{3}\right.$-weighted, $3.5<k<13 \AA^{-1}$, Pt-C phase corrected) of raw EXAFS data at $\mathrm{Pt} \mathrm{L}_{\text {III }}$ edge minus calculated metal-metal contributions $\left(\mathrm{Pt}-\mathrm{Pt}+\mathrm{Pt}-\mathrm{Ru}\right.$ ) for Pt-Ruco $/ \mathrm{C}$ (black line) and $\mathrm{Pt}-\mathrm{Ru}_{\mathrm{se}} / \mathrm{C}$ (red line); (b) imaginary part and magnitude of Fourier transform $\left(k^{1}-\right.$ weighted, $3.0<k<14 \AA^{-1}$, Ru-Cl phase corrected) of raw EXAFS data at Ru K edge minus calculated metal-metal contributions (Ru-Ru $\left.+\mathrm{Ru}-\mathrm{Pt}\right)$ for $\mathrm{Pt}-\mathrm{Ru}_{\mathrm{co}} / \mathrm{C}$ (black line) and $\mathrm{Pt}-\mathrm{Ru}_{\mathrm{se}} / \mathrm{C}$ (red line).

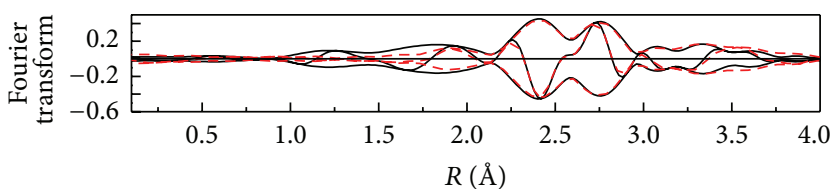

(a)

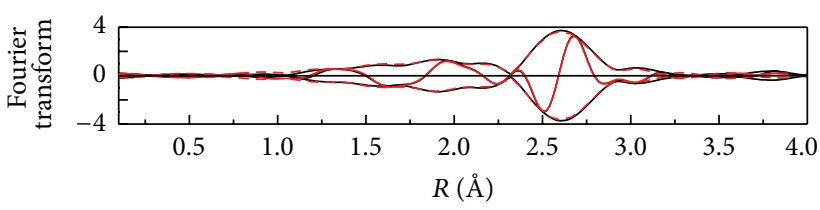

(c)

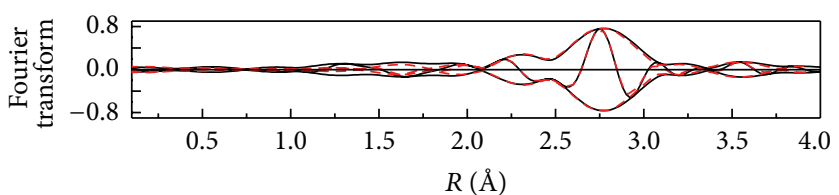

(b)

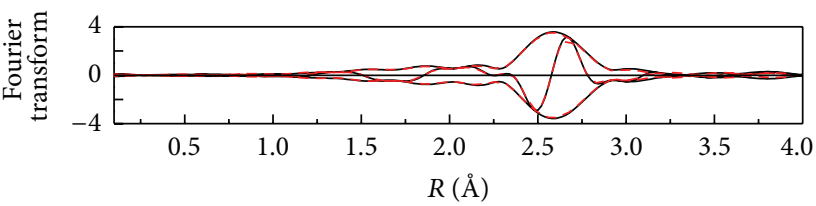

(d)

FIGURE 6: Comparison of imaginary part and magnitude of Fourier transform $\left(k^{2}\right.$-weighted, $3.0<k<16 \AA^{-1}$, Pt-Pt phase and amplitude corrected) of raw EXAFS data at $\mathrm{Pt} \mathrm{L}_{\mathrm{III}}$ edge (solid line) and sum of the calculated contributions (dashed line) for (a) $\mathrm{Pt}-\mathrm{Ru} \mathrm{co}_{\mathrm{o}} / \mathrm{C}$ and $(\mathrm{b})$ $\mathrm{Pt}-\mathrm{Ru}_{\mathrm{se}} / \mathrm{C}$. Comparison of imaginary part and magnitude of Fourier transform raw EXAFS data at Ru K edge $\left(k^{2}\right.$-weighted, $3.0<k<14 \AA^{-1}$, $\mathrm{Ru}-\mathrm{Ru}$ phase and amplitude corrected) of experimental EXAFS data (solid line) at Ru K edge and sum of the calculated contributions (dashed line) for (c) $\mathrm{Pt}-\mathrm{Ru}_{\mathrm{co}} / \mathrm{C}$ and (d) $\mathrm{Pt}-\mathrm{Ru}_{\mathrm{se}} / \mathrm{C}$.

More accurate parameters for $\mathrm{Ru}-\mathrm{Ru}$ and $\mathrm{Ru}-\mathrm{Pt}$ were then estimated by the subtraction of the calculated $\mathrm{Ru}-\mathrm{Cl}$ and $\mathrm{Ru}-$ $\mathrm{C}\left(\mathrm{Ru}-\mathrm{O}^{*}\right)$ from raw data. The recursive iteration was carried out until a satisfactory overall fit was reached. The results of the EXAFS analysis at $\mathrm{Pt}$ and $\mathrm{Ru}$ edge were summarized in Tables 1 and 2, respectively, and the comparison of the data and the fit are shown in Figure 6.

As shown in Figure 7, the ratios of the Pt-Ru and PtPt characteristic peak intensity $\left(I_{\mathrm{Pt}-\mathrm{Ru}} / I_{\mathrm{Pt}-\mathrm{Pt}}\right)$ are correlated well with that of coordination number $\left(N_{\mathrm{Pt}-\mathrm{Ru}} / N_{\mathrm{Pt}-\mathrm{Pt}}\right)$. Since $N_{\mathrm{Pt}-\mathrm{Ru}}$ represents the number of $\mathrm{Ru}$ atoms neighboring to a $\mathrm{Pt}$ atom, the higher the $N_{\mathrm{Pt}-\mathrm{Ru}}$, the greater the Pt-Ru bimetallic interaction. By use of this correlation, the extent of bimetallic interactions can thus easily be estimated by the use of phase-and-amplitude corrected Fourier transform instead of tedious and time-consuming detailed EXAFS analysis. The extent of bimetallic interaction is an important consideration in bimetallic catalyst development. In developing commercial catalysts, many samples will be prepared. To save time and expensive catalytic performance tests, the method proposed here can be used for quick screening of promising catalyst samples for the performance tests.
3.4. TPR Characterizing Pt-Pd and Pt-Re Catalysts and EXAFS Characteristic Peaks of Pt-Pd Bimetallic Interactions. In contrast to $\mathrm{Pt} / \gamma-\mathrm{Al}_{2} \mathrm{O}_{3}$ at 270 and $\mathrm{Re} / \gamma-\mathrm{Al}_{2} \mathrm{O}_{3}$ at $520^{\circ} \mathrm{C}$, only one peak was observed in TPR characterizing Pt- Re $/ \gamma-\mathrm{Al}_{2} \mathrm{O}_{3}$ catalyst at $310^{\circ} \mathrm{C}$, as shown in Figure 8 (a). The results are consistent with TPR results reported in the literature for Pt-Re catalysts predried by $\mathrm{He}$ at low temperature $\left(<300^{\circ} \mathrm{C}\right)$ before $\mathrm{H}_{2}$ reduction [39]. Inferred from TPR and EXAFS characterizing $\mathrm{Pt}-\mathrm{Ru}_{\mathrm{co}} / \mathrm{C}$, the apparent reduction of a single peak indicates the formation of bimetallic interactions; besides the catalytic reduction of Re species by $\mathrm{Pt}$ as postulated in the literature $[39,51,72,73]$, Pt-Re bimetallic interactions can also be formed from reaction of the mobile hydrated ReOx species and reduced Pt clusters.

The TPR profiles characterizing $\mathrm{PtO}_{2} / \gamma-\mathrm{Al}_{2} \mathrm{O}_{3}$, $\mathrm{Pd}(\mathrm{OAc})_{2} / \gamma-\mathrm{Al}_{2} \mathrm{O}_{3}$, and $\mathrm{PtO}_{2}-\mathrm{Pd}(\mathrm{OAc})_{2} / \gamma-\mathrm{Al}_{2} \mathrm{O}_{3}$ are shown in Figure $8(\mathrm{~b})$. It is apparent that the main reductive decomposition of acetate ligands in $\mathrm{Pd}(\mathrm{OAc})_{2}$ on $\gamma-\mathrm{Al}_{2} \mathrm{O}_{3}$ is at $470^{\circ} \mathrm{C}$. In the presence of $\mathrm{Pt}$, the reductive decomposition temperature decreased by about $50^{\circ} \mathrm{C}$. The results combined with the long term stability tests [55] suggest the existence of a significant Pd-Pt bimetallic interaction. The exploration of 
TABLE 2: Summary of EXAFS analysis results for Pt-Ru catalysts at Ru edge.

\begin{tabular}{|c|c|c|c|c|c|}
\hline Shell & $N^{\mathrm{a}}$ & $\begin{array}{l}R^{\mathrm{b}} \\
(\AA) \\
\end{array}$ & $\begin{array}{c}1000 \times \Delta \sigma^{2 c} \\
\left(\AA^{2}\right)\end{array}$ & $\begin{array}{l}\Delta E_{0}^{\mathrm{d}} \\
(\mathrm{eV})\end{array}$ & EXAFS reference \\
\hline \multicolumn{6}{|c|}{ (a) Pt-Rublack } \\
\hline $\mathrm{Ru}-\mathrm{Ru}$ & $4.2(2)$ & $2.65(4)$ & $7.0(3)$ & $6.6(3)$ & $\mathrm{RuRu}$ \\
\hline $\mathrm{Ru}-\mathrm{Pt}$ & $2.6(2)$ & $2.71(1)$ & $5.8^{* \mathrm{f}}$ & $9.9(7)$ & $\mathrm{RuPt}$ \\
\hline \multicolumn{6}{|c|}{ (b) $\mathrm{Pt}-\mathrm{Ru}_{\mathrm{co}} / \mathrm{C}$} \\
\hline $\mathrm{Ru}-\mathrm{Cl}$ & $1.1(1)$ & $2.31(1)$ & $6.5(2)$ & $5(2)$ & $\mathrm{RuCl}$ \\
\hline $\mathrm{Ru}-\mathrm{Ru}$ & $3.8(3)$ & $2.65(4)$ & $5.2(5)$ & $5(1)$ & $\mathrm{RuRu}$ \\
\hline $\mathrm{Ru}-\mathrm{Pt}$ & $1.1(3)$ & $2.70(2)$ & $4.3^{* \mathrm{f}}$ & $5(3)$ & $\mathrm{RuPt}$ \\
\hline $\mathrm{Ru}-\mathrm{O}_{\mathrm{s}}$ & $1.0(3)$ & $3.39(4)$ & $2.4(5)$ & $-8(2)$ & $\mathrm{RuO}$ \\
\hline \multicolumn{6}{|c|}{ (c) $\mathrm{Pt}-\mathrm{Ru}_{\mathrm{se}} / \mathrm{C}$} \\
\hline $\mathrm{Ru}-\mathrm{Cl}$ & $0.8(2)$ & $2.32(3)$ & $8.2(4)$ & $7(1)$ & $\mathrm{RuCl}$ \\
\hline $\mathrm{Ru}-\mathrm{Ru}$ & $4.1(2)$ & $2.64(3)$ & $6.1(3)$ & $6(1)$ & $\mathrm{RuRu}$ \\
\hline $\mathrm{Ru}-\mathrm{Pt}$ & $0.4(1)$ & $2.68(3)$ & $4.7^{* \mathrm{f}}$ & $-5(3)$ & $\mathrm{RuPt}$ \\
\hline
\end{tabular}

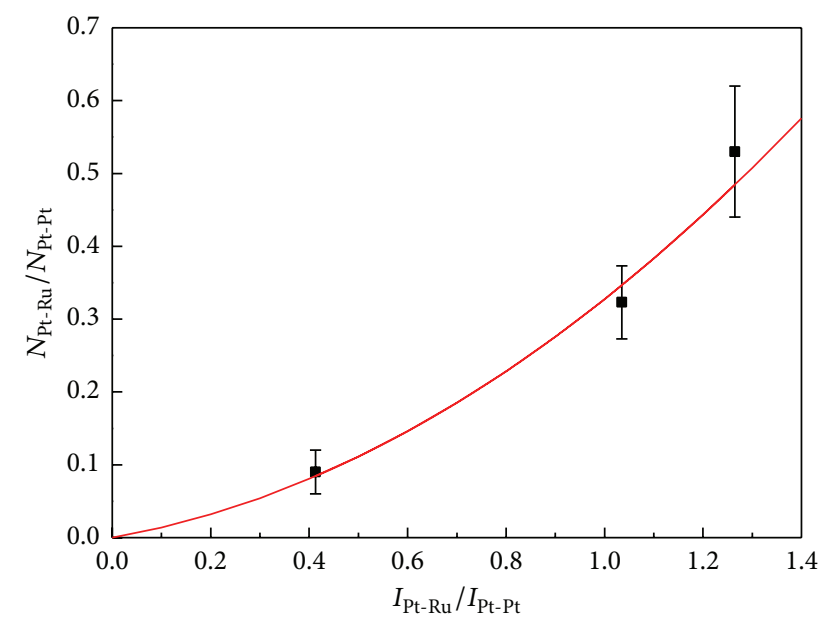

Figure 7: Correlation between the ratio of Pt-Ru to Pt-Pt characteristic peak intensity $\left(I_{\mathrm{Pt}-\mathrm{Ru}} / I_{\mathrm{Pt}-\mathrm{Pt}}\right)$ and the ratio of Pt-Ru to Pt-Pt coordination number $\left(N_{\mathrm{Pt}-\mathrm{Ru}} / N_{\mathrm{Pt}-\mathrm{Pt}}\right)$.

EXAFS characteristic peaks for Pt-Re and Pt-Pd interaction, respectively, is illustrated as follows.

A comparison of the Pt-Pt phase-and-amplitude corrected Fourier transform of the EXAFS spectra at Pt edge for $\mathrm{Pt}$ foil, $\mathrm{Pt} / \gamma-\mathrm{Al}_{2} \mathrm{O}_{3(\mathrm{~d})}$, and $\mathrm{Pt}-\mathrm{Re} / \gamma-\mathrm{Al}_{2} \mathrm{O}_{3(\mathrm{~d})}$ shows that major peak is located at a distance of 2.7-2.8 $\AA$, consistent with the metal-metal distance of bulk Pt and bulk Re (Figure 9(a)). The metal-metal distance in $\mathrm{Pt}$ foil and that in $\mathrm{Pt} / \gamma-\mathrm{Al}_{2} \mathrm{O}_{3 \text { (d) }}$ are about the same, whereas the distance characterizing $\mathrm{Pt}-\mathrm{Re} / \gamma-\mathrm{Al}_{2} \mathrm{O}_{3(\mathrm{~d})}$ is significantly shorter (Figure 9(a)). A shortening of the metal-metal distance for $\mathrm{Pt}-\mathrm{Re} / \gamma-\mathrm{Al}_{2} \mathrm{O}_{3 \text { (d) }}$ may suggest the formation of Pt-Re bimetallic interactions $[19,69]$. However, because the phase function for Pt-Pt is only slightly different from that for Pt-Re, no significant characteristic peak was observed in the Fourier transformed EXAFS. Similarly, a comparison of the Re-Re phase-andamplitude corrected Fourier transformed EXAFS data at Re edge shows that metal-metal distance in $\mathrm{Pt}-\mathrm{Re} / \gamma-\mathrm{Al}_{2} \mathrm{O}_{3(\mathrm{~d})}$ is shorter than that in $\mathrm{Re} / \gamma-\mathrm{Al}_{2} \mathrm{O}_{3(\mathrm{~d})}$, consistent with the formation of $\mathrm{Pt}-\mathrm{Re}$ bimetallic interactions.

For Pt-Re $/ \gamma-\mathrm{Al}_{2} \mathrm{O}_{3}$, an additional peak appearing at about $3.4 \AA$ cannot be assigned as the characteristic peak for Re$\mathrm{Pt}$ because the phase functions of $\mathrm{Re}-\mathrm{Pt}$ and $\mathrm{Re}-\mathrm{Re}$ are very similar to each other; moreover, when experimentally determined Re-Re phase and amplitude function was applied, no significant peaks appear in $R$ ranging from 3.0 to $3.5 \AA$. (Figure 9(c)). The discrepancy for the Fourier transforms corrected by theoretical and experimental phase and amplitude function could be caused by the side lobe generated from the finite range of the Fourier transform or the difference of amplitude functions obtained from theoretical and experimental methods.

Since the affinity of Pt-Re and Pt-Pd clusters to $\gamma$ $\mathrm{Al}_{2} \mathrm{O}_{3}$ is higher than $\mathrm{Pt}-\mathrm{Ru}$ to carbon, the contributions from low atomic weight scatterers, such as the oxygen atoms of the support, are more pronounced for Pt-Re $/ \gamma-\mathrm{Al}_{2} \mathrm{O}_{3 \text { (d) }}$ and $\mathrm{Pt}-\mathrm{Pd} / \gamma-\mathrm{Al}_{2} \mathrm{O}_{3}$ than that for $\mathrm{Pt}-\mathrm{Ru} / \mathrm{C}$. In exploring the characteristic peak of Pt-Re and Pt-Pd, to minimize the interference from low atomic weight scatters, $k^{3}$-weighted $\mathrm{Pt}$-Pt phase-and-amplitude corrected Fourier transforms of the EXAFS functions were determined at the Pt edge for the $\gamma-\mathrm{Al}_{2} \mathrm{O}_{3}$ supported catalyst samples. Similar to the Fourier transformed EXAFS for $\mathrm{Pt}-\mathrm{Ru}_{\text {black}}$, for $\mathrm{Pt}-\mathrm{Pd} / \gamma-\mathrm{Al}_{2} \mathrm{O}_{3}$, a positive peak at about $2.7 \AA$ combined with a shoulder (peak) at $2.45 \AA$ was observed in imaginary part of the Fourier transformed EXAFS (Figure 10(a)). The peak at $2.45 \AA$ was 


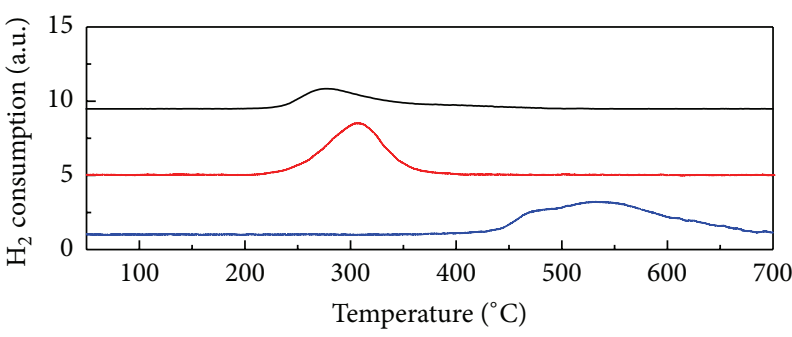

(a)

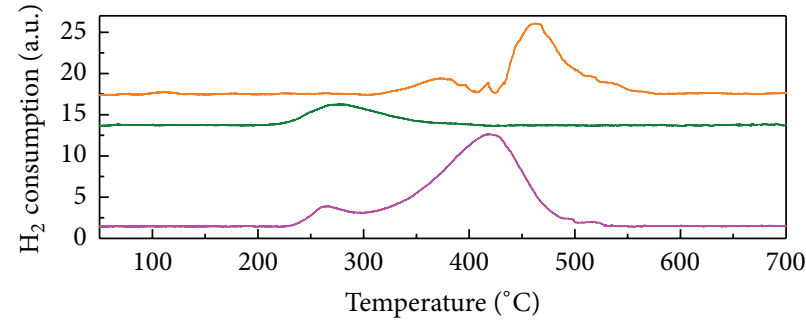

(b)

Figure 8: TPR profiles for $\gamma-\mathrm{Al}_{2} \mathrm{O}_{3}$ supported catalysts: (a) Re $/ \gamma-\mathrm{Al}_{2} \mathrm{O}_{3 \text { (d) }}$ (blue line), $\mathrm{Pt}-\mathrm{Re} / \gamma-\mathrm{Al}_{2} \mathrm{O}_{3 \text { (d) }}$ (red line), and $\mathrm{Pt} / \gamma$ - $\mathrm{Al}_{2} \mathrm{O}_{3(\mathrm{~d})}$ (black line); (b) $\mathrm{Pd}(\mathrm{OAc})_{2} / \gamma-\mathrm{Al}_{2} \mathrm{O}_{3}$ (orange line), $\mathrm{Pt} / \gamma-\mathrm{Al}_{2} \mathrm{O}_{3}$ (olive line), and $\mathrm{Pt}-\mathrm{Pd}(\mathrm{OAc}) / \gamma-\mathrm{Al}_{2} \mathrm{O}_{3}$ (magenta line).

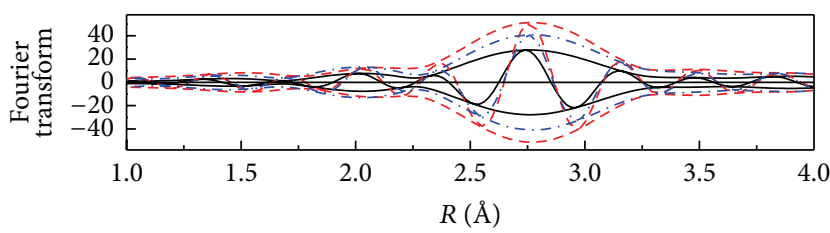

(a)

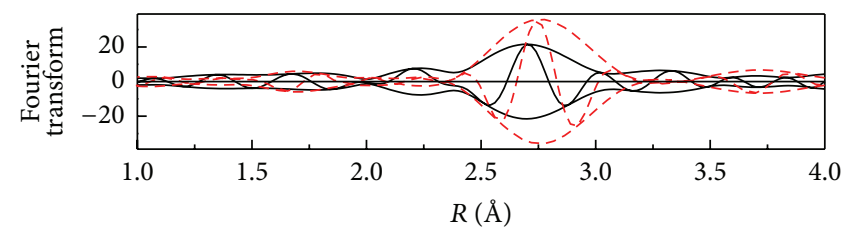

(b)

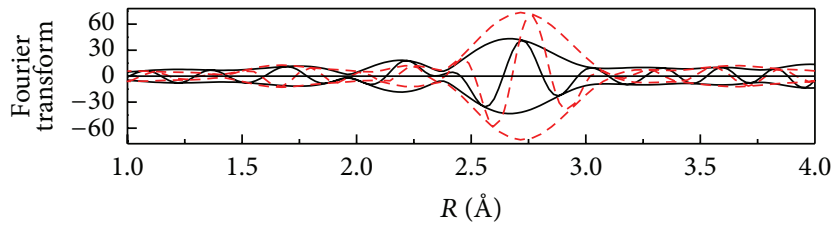

(c)

FIGURE 9: Comparison of (a) imaginary part and magnitude of Fourier transform ( $k^{3}$-weighted, $3.0<k<9.5 \AA^{-1}$, Pt-Pt phase and amplitude corrected) of experimental EXAFS data at Pt edge for Pt-Re $/ \gamma-\mathrm{Al}_{2} \mathrm{O}_{3(\mathrm{~d})}$ (black line), Pt foil (red line), and $\mathrm{Pt} / \gamma-\mathrm{Al}_{2} \mathrm{O}_{3(\mathrm{~d})}$ (blue line); (b) imaginary part and magnitude of Fourier transform $\left(k^{3}\right.$-weighted, $4.0<k<14 \AA^{-1}$, Re-Re $e_{\text {(theortical }}$ phase and amplitude corrected) of experimental EXAFS data at Re edge for Pt-Re $/ \gamma-\mathrm{Al}_{2} \mathrm{O}_{3(\mathrm{~d})}$ and $\mathrm{Re} / \gamma-\mathrm{Al}_{2} \mathrm{O}_{3(\mathrm{~d})}$ (red line); (c) imaginary part and magnitude of Fourier transform ( $k^{3}$-weighted, $4.0<k<14 \AA^{-1}, \operatorname{Re}-\operatorname{Re}_{(\text {experimental) }}$ phase and amplitude corrected) of experimental EXAFS data at Re edge for Pt-Re/ $\gamma$ - $\mathrm{Al}_{2} \mathrm{O}_{3(\mathrm{~d})}$ and $\mathrm{Re} / \gamma-\mathrm{Al}_{2} \mathrm{O}_{3(\mathrm{~d})}$ (red line).

thus assigned as the characteristic peak of Pt-Pd contribution. The appearance of Pt-Pd characteristic peak indicates the existence of Pd-Pt contribution. As shown in Figures 10(b) and 10(a), comparison of Pd-Pd phase-and-amplitude corrected Fourier transformed EXAFS functions for Pt-Pd $/ \gamma$ $\mathrm{Al}_{2} \mathrm{O}_{3}$ and $\mathrm{Pd} / \gamma-\mathrm{Al}_{2} \mathrm{O}_{3}$ at $\mathrm{Pd}$ edge shows that the main peak of $\mathrm{Pt}-\mathrm{Pd} / \gamma-\mathrm{Al}_{2} \mathrm{O}_{3}$ is located at a longer $R$ than that of $\mathrm{Pd} / \gamma$ $\mathrm{Al}_{2} \mathrm{O}_{3}$. The coupling of $\mathrm{Pd}-\mathrm{Pt}$ and $\mathrm{Pd}-\mathrm{Pd}$ contributions results in a shift of $R$ to longer distance. However, we are unable to assign a characteristic peak for Pd-Pt because of the superposition of the peak with $\mathrm{Pd}-\mathrm{Pd}$ characteristic peak; a small peak appearing at $3.1 \AA$ could be contributed by $\mathrm{Pd}$ $\mathrm{Pt}$ absorber-backscatter pair, whereas its intensity is only slightly higher than that of the side lobe of the main peak and is hard for the estimation of the extent of Pt-Pd bimetallic interactions.

\section{Conclusions}

$\mathrm{Pt}-\mathrm{Ru}$ bimetallic interaction can easily be detected by Pt-Pt phase-and-amplitude corrected Fourier transformed EXAFS function and the $\mathrm{Pt}-\mathrm{Ru}$ contributions were characterized by the peak appearing at $2.5 \AA \AA$. Moreover, after detailed EXAFS analysis of $\mathrm{Pt}-\mathrm{Ru}_{\mathrm{co}} / \mathrm{C}, \mathrm{Pt}-\mathrm{Ru}_{\mathrm{se}} / \mathrm{C}$, and $\mathrm{Pt}-\mathrm{Ru}_{\text {black }}$ by combined difference file technique and multishell fitting routine, we found that $I_{\mathrm{Pt}-\mathrm{Ru}} / I_{\mathrm{Pt}-\mathrm{Pt}}$ are correlated well with $N_{\mathrm{Pt}-\mathrm{Ru}} / N_{\mathrm{Pt}-\mathrm{Pt}}$. Since $N_{\mathrm{Pt}-\mathrm{Ru}} / N_{\mathrm{Pt}-\mathrm{Pt}}$ is the indication of the extent of bimetallic interaction, $\mathrm{Pt}-\mathrm{Ru}$ bimetallic interaction can semiquantitatively be determined by simple Fourier transform technique using $I_{\mathrm{Pt}-\mathrm{Ru}} / I_{\mathrm{Pt}-\mathrm{Pt}}$.

The method proposed in this study can be extended to characterize $\mathrm{Pt}-\mathrm{Pd} / \gamma-\mathrm{Al}_{2} \mathrm{O}_{3}$ bimetallic interaction because the phase function of $\mathrm{Pt}-\mathrm{Pd}$ is significantly different from that of Pt-Pt. In contrast, the method cannot be applied to Pt-Re catalysts because the phase functions of Pt-Pt and Pt-Re are similar and the Fourier transform ranges are limited by the appearance of the Re $\mathrm{L}_{\mathrm{III}}$ absorption edge.

Traditionally, TPR has been used to characterize bimetallic interactions whereas it is not a conclusive technique to quantify the interactions. By comparing the EXAFS and TPR results, we found that $\mathrm{Pt}-\mathrm{M}_{2 \text { nd }}$ catalysts characterized by TPR with a single peak do show bimetallic interaction, in agreement with the interpretation of most of the researchers. However, for bimetallic catalysts with separated 


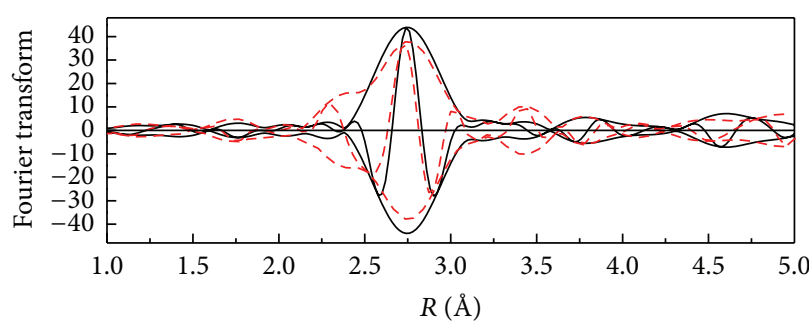

(a)

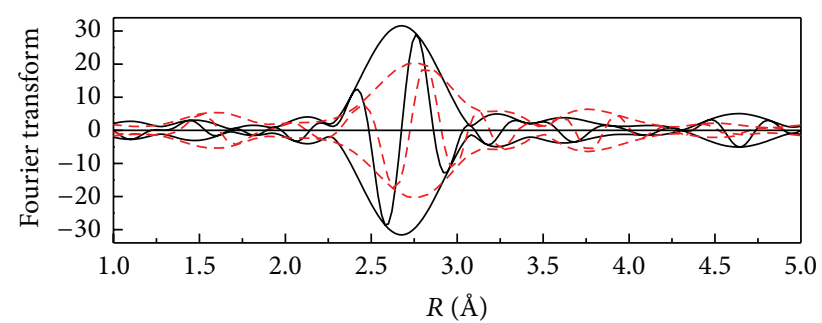

(b)

FIGURE 10: (a) Imaginary part and magnitude of Fourier transform $\left(k^{3}\right.$-weighted, $4.0<k<15 \AA^{-1}$, Pt-Pt phase and amplitude corrected) of experimental EXAFS data at Pt edge for Pt $/ \gamma-\mathrm{Al}_{2} \mathrm{O}_{3}$ (black line) and Pt-Pd $/ \gamma-\mathrm{Al}_{2} \mathrm{O}_{3}$ (red line). (b) Imaginary part and magnitude of Fourier transform ( $k^{3}$-weighted, $4.0<k<13 \AA^{-1}$, Pd-Pd phase and amplitude corrected) of experimental EXAFS data at $\mathrm{Pd}$ edge for $\mathrm{Pd} / \gamma$ - $\mathrm{Al}_{2} \mathrm{O}_{3}$ (black line) and Pt-Pd $/ \gamma-\mathrm{Al}_{2} \mathrm{O}_{3}$ (red line).

peaks in TPR profile, the existence of bimetallic interactions remains the subject of discussion. However, in this study, EXAFS conclusively indicates that these kinds of catalysts can have bimetallic interactions. Furthermore, the correlation of $N_{\mathrm{Pt}-\mathrm{M}} / N_{\mathrm{Pt}-\mathrm{Pt}}$ with TPR results suggests that the extent of bimetallic interactions is in the following order: one TPR peak $>$ two separated peaks with 2 nd metal reduction peak shifting to lower temperature $>$ two separated peaks without a significant peak shift.

\section{Conflict of Interests}

The authors declare that there is no conflict of interests regarding the publication of this paper.

\section{Acknowledgments}

The EXAFS data were analyzed using the FEFF and XDAP Data Analysis Program. XDAP program was developed by M. Vaarkam, J. C. Linders, and D. C. Koningsberger. The support of National Science Council, Taiwan (Contract no. NSC101-2221-E-194-052), and National Synchrotron Radiation Research Center (NSRRC) is acknowledged.

\section{References}

[1] S. Alayoglu, A. U. Nilekar, M. Mavrikakis, and B. Eichhorn, "RuPt core-shell nanoparticles for preferential oxidation of carbon monoxide in hydrogen," Nature Materials, vol. 7, no. 4, pp. 333$338,2008$.

[2] A. D. Modestov, M. R. Tarasevich, V. Y. Filimonov, and E. S. Davydova, "CO tolerance and $\mathrm{CO}$ oxidation at Pt and Pt$\mathrm{Ru}$ anode catalysts in fuel cell with polybenzimidazole- $\mathrm{H}_{3} \mathrm{PO}_{4}$ membrane," Electrochimica Acta, vol. 55, no. 20, pp. 6073-6080, 2010.

[3] C. Jung, J. Kim, and C. K. Rhee, "CO preoxidation on Ru-modified Pt(111)," Electrochemistry Communications, vol. 12, no. 10, pp. 1363-1366, 2010.

[4] A. Velázquez-Palenzuela, E. Brillas, C. Arias et al., "Structural characterization of Ru-modified carbon-supported pt nanoparticles using spontaneous deposition with CO oxidation activity," The Journal of Physical Chemistry C, vol. 116, no. 34, pp. 1846918478, 2012.
[5] T. Sato, K. Okaya, K. Kunimatsu, H. Yano, M. Watanabe, and H. Uchida, "Effect of particle size and composition on COtolerance at $\mathrm{Pt}-\mathrm{Ru} / \mathrm{C}$ Catalysts analyzed by in situ attenuated total reflection FTIR Spectroscopy," ACS Catalysis, vol. 2, no. 3, pp. 450-455, 2012.

[6] T. R. Ralph and M. P. Hogarth, "Catalysis for low temperature fuel cells," Platinum Metals Review, vol. 46, no. 3, pp. 117-135, 2002.

[7] S. D. Lin, T.-C. Hsiao, J.-R. Chang, and A. S. Lin, "Morphology of carbon supported Pt-Ru electrocatalyst and the CO tolerance of anodes for PEM fuel cells," The Journal of Physical Chemistry $B$, vol. 103, no. 1, pp. 97-103, 1999.

[8] D.-G. Liu, J.-F. Lee, and M.-T. Tang, "Characterization of Pt$\mathrm{Ru} / \mathrm{C}$ catalysts by X-ray absorption spectroscopy and temperature-programmed surface reaction," Journal of Molecular Catalysis A: Chemical, vol. 240, no. 1-2, pp. 197-206, 2005.

[9] H. Li, D. Kang, H. Wang, and R. Wang, "Carbon-supported PtRuCo nanoparticles with low-noble-metal content and superior catalysis for ethanol oxidization," International Journal of Electrochemical Science, vol. 6, no. 4, pp. 1058-1065, 2011.

[10] T. Takeguchi, T. Yamanaka, K. Asakura, E. N. Muhamad, K. Uosaki, and W. Ueda, "Evidence of nonelectrochemical shift reaction on a CO-tolerant high-entropy state $\mathrm{Pt}-\mathrm{Ru}$ anode catalyst for reliable and efficient residential fuel cell systems," Journal of the American Chemical Society, vol. 134, no. 35, pp. 14508-14512, 2012.

[11] Y. Yoshimura, H. Yasuda, T. Sato, N. Kijima, and T. Kameoka, "Sulfur-tolerant Pd-Pt/Yb-USY zeolite catalysts used to reformulate diesel oils," Applied Catalysis A: General, vol. 207, no. 1-2, pp. 303-307, 2001.

[12] L. S. Carvalho, C. L. Pieck, M. do Carmo Rangel, N. S. Fígoli, and J. M. Parera, "Sulfur poisoning of Bi- and trimetallic $\gamma-\mathrm{Al}_{2} \mathrm{O}_{3}$ supported Pt, Re, and Sn catalysts," Industrial \& Engineering Chemistry Research, vol. 43, no. 5, pp. 1222-1226, 2004.

[13] T. Matsui, M. Harada, Y. Ichihashi et al., "Effect of noble metal particle size on the sulfur tolerance of monometallic Pd and Pt catalysts supported on high-silica USY zeolite," Applied Catalysis A: General, vol. 286, no. 2, pp. 249-257, 2005.

[14] Y. Yoshimura, M. Toba, T. Matsui et al., "Active phases and sulfur tolerance of bimetallic Pd-Pt catalysts used for hydrotreatment," Applied Catalysis A: General, vol. 322, pp. 152-171, 2007.

[15] H. Zhang, X. Meng, Y. Li, and Y. S. Lin, "MCM-41 overgrown on y composite zeolite as support of Pd-Pt catalyst for hydrogenation of polyaromatic compounds," Industrial \& Engineering Chemistry Research, vol. 46, no. 12, pp. 4186-4192, 2007. 
[16] A. Gutiérrez, J. M. Arandes, P. Castaño, M. Olazar, A. Barona, and J. Bilbao, "Effect of space velocity on the hydrocracking of light cycle oil over a Pt-Pd/HY zeolite catalyst," Fuel Processing Technology, vol. 95, pp. 8-15, 2012.

[17] A. Gutiérrez, J. M. Arandes, P. Castaño, M. Olazar, and J. Bilbao, "Enhancement of aromatic hydro-upgrading on a $\mathrm{Pt}$ catalyst by promotion with Pd and shape-selective supports," Fuel Processing Technology, vol. 101, pp. 64-72, 2012.

[18] Y. Yu, B. Fonfé, A. Jentys et al., "Bimetallic Pt-Pd/silica-alumina hydrotreating catalysts-part II: structure-activity correlations in the hydrogenation of tetralin in the presence of dibenzothiophene and quinolone," Journal of Catalysis, vol. 292, pp. 13-25, 2012.

[19] A. S. Fung, M. J. Kelley, D. C. Koningsberger, and B. C. Gates, " $\gamma$ - $\mathrm{Al}_{2} \mathrm{O}_{3}$-supported Re-Pt cluster catalyst prepared from $\left[\mathrm{Re}_{2} \mathrm{Pt}(\mathrm{CO})_{12}\right]$ : characterization by extended X-ray absorption fine structure spectroscopy and catalysis of methylcyclohexane dehydrogenation," Journal of the American Chemical Society, vol. 119 , no. 25 , pp. 5877-5887, 1997.

[20] S.-Y. Huang, C.-M. Chang, and C.-T. Yeh, "Promotion of platinum-ruthenium catalyst for electro-oxidation of methanol by ceria," Journal of Catalysis, vol. 241, no. 2, pp. 400-406, 2006.

[21] S. Cimino and L. Lisi, "Impact of sulfur poisoning on the catalytic partial oxidation of methane on rhodium-based catalysts," Industrial \& Engineering Chemistry Research, vol. 51, no. 22, pp. 7459-7466, 2012.

[22] H. Yang, W. Vogel, C. Lamy, and N. Alonso-Vante, "Structure and electrocatalytic activity of carbon-supported Pt-Ni alloy nanoparticles toward the oxygen reduction reaction," The Journal of Physical Chemistry B, vol. 108, no. 30, pp. 11024-11034, 2004.

[23] Q. Huang, H. Yang, Y. Tang, T. Lu, and D. L. Akins, "Carbonsupported Pt-Co alloy nanoparticles for oxygen reduction reaction," Electrochemistry Communications, vol. 8, no. 8, pp. 1220-1224, 2006.

[24] E. Guillon, B. Didillon, and D. Uzio, "Aromatic reduction over supported modified platinum catalysts influence of a second metal on the sulfur resistance of platinum," Oil and Gas Science and Technology, vol. 61, no. 3, pp. 405-413, 2006.

[25] I.-S. Park, K.-W. Park, J.-H. Choi, C. R. Park, and Y.-E. Sung, "Electrocatalytic enhancement of methanol oxidation by graphite nanofibers with a high loading of $\mathrm{PtRu}$ alloy nanoparticles," Carbon, vol. 45, no. 1, pp. 28-33, 2007.

[26] S.-H. Liu, W.-Y. Yu, C.-H. Chen et al., "Fabrication and characterization of well-dispersed and highly stable PtRu nanoparticles on carbon mesoporous material for applications in direct methanol fuel cell," Chemistry of Materials, vol. 20, no. 4, pp. 1622-1628, 2008.

[27] A. Ciftci, D. A. J. M. Ligthart, A. Oben Sen, A. J. F. van Hoof, H. Friedrich, and E. J. M. Hensen, "Pt-Re synergy in aqueousphase reforming of glycerol and the water-gas shift reaction," Journal of Catalysis, vol. 311, pp. 88-101, 2014.

[28] M. A. Rigsby, W.-P. Zhou, A. Lewera et al., "Experiment and theory of fuel cell catalysis: methanol and formic acid decomposition on nanoparticle $\mathrm{Pt} / \mathrm{Ru}$," The Journal of Physical Chemistry C, vol. 112, no. 39, pp. 15595-15601, 2008.

[29] M. Umeda, Y. Matsumoto, M. Inoue, and S. Shironita, " $\mathrm{O}_{2}$ enhanced methanol oxidation reaction at novel $\mathrm{Pt}-\mathrm{Ru}-\mathrm{C}$ cosputtered electrodes," Electrochimica Acta, vol. 101, no. 1, pp. 142-150, 2013.

[30] T. Arikan, A. M. Kannan, and F. Kadirgan, "Binary Pt-Pd and ternary Pt-Pd-Ru nanoelectrocatalysts for direct methanol fuel cells," International Journal of Hydrogen Energy, vol. 38, no. 6, pp. 2900-2907, 2013.

[31] J. R. Kitchin, J. K. Nørskov, M. A. Barteau, and J. G. Chen, "Modification of the surface electronic and chemical properties of $\mathrm{Pt}(111)$ by subsurface $3 \mathrm{~d}$ transition metals," Journal of Chemical Physics, vol. 120, no. 21, pp. 10240-10246, 2004.

[32] M. Watanabe, T. Sato, K. Kunimatsu, and H. Uchida, "Temperature dependence of co-adsorption of carbon monoxide and water on highly dispersed $\mathrm{Pt} / \mathrm{C}$ and $\mathrm{PtRu} / \mathrm{C}$ electrodes studied by in-situ ATR-FTIRAS," Electrochimica Acta, vol. 53, no. 23, pp. 6928-6937, 2008.

[33] N. Dimakis, H. Iddir, R. R. Díaz-Morales et al., "A band dispersion mechanism for Pt alloy compositional tuning of linear bound CO stretching frequencies," The Journal of Physical Chemistry B, vol. 109, no. 5, pp. 1839-1848, 2005.

[34] B. Y. Liu, J. M. Jin, C. Hardacre, P. Hu, and W. F. Lin, "Combined studies of DFT atomistic modelling and in situ FTIR spectroscopy on surface oxidants and $\mathrm{CO}$ oxidation at $\mathrm{Ru}$ electrodes," Journal of Electroanalytical Chemistry, vol. 688, pp. 216-223, 2013.

[35] A. C. Johansson, J. V. Larsen, M. A. Verheijen et al., "Electrocatalytic activity of atomic layer deposited $\mathrm{Pt}-\mathrm{Ru}$ catalysts onto $\mathrm{N}$-doped carbon nanotubes," Journal of Catalysis, vol. 311, pp. 418-486, 2014

[36] Y. Zhao, L. Fan, J. Ren, and B. Hong, "Electrodeposition of $\mathrm{Pt}-\mathrm{Ru}$ and $\mathrm{Pt}-\mathrm{Ru}-\mathrm{Ni}$ nanoclusters on multi-walled carbon nanotubes for direct methanol fuel cell," International Journal of Hydrogen Energy, vol. 39, no. 9, pp. 4544-4557, 2014.

[37] C. Xie, Y. Chen, M. H. Engelhard, and C. Song, "Comparative study on the sulfur tolerance and carbon resistance of supported noble metal catalysts in steam reforming of liquid hydrocarbon fuel," ACS Catalysis, vol. 2, no. 6, pp. 1127-1137, 2012.

[38] J. Kua and W. A. Goddard III, "Oxidation of methanol on 2nd and 3rd row group VIII transition metals (Pt, Ir, Os, Pd, Rh, and $\mathrm{Ru}$ ): application to direct methanol fuel cells," Journal of the American Chemical Society, vol. 121, no. 47, pp. 10928-10941, 1999.

[39] B. H. Isaacs and E. E. Petersen, "The effect of drying temperature on the temperature-programmed reduction profile of a platinum/rhenium/alumina catalyst," Journal of Catalysis, vol. 77, no. 1, pp. 43-52, 1982.

[40] L. S. Carvalho, C. L. Pieck, M. C. Rangel et al., "Trimetallic naphtha reforming catalysts. I. Properties of the metal function and influence of the order of addition of the metal precursors on Pt-Re-Sn $/ \gamma-\mathrm{Al}_{2} \mathrm{O}_{3}$-Cl," Applied Catalysis A: General, vol. 269, no. 1-2, pp. 91-103, 2004.

[41] M. D. Shannon, C. M. Lok, and J. L. Casci, "Imaging promoter atoms in Fischer-Tropsch cobalt catalysts by aberrationcorrected scanning transmission electron microscopy," Journal of Catalysis, vol. 249, no. 1, pp. 41-51, 2007.

[42] F. Diehl and A. Y. Khodakov, "Promotion of Cobalt FischerTropsch catalysts with noble metals: a review," Oil \& Gas Science and Technology-Revue de l'IFP, vol. 64, no. 1, pp. 11-24, 2009.

[43] Y. Amada, Y. Shinmi, S. Koso, T. Kubota, Y. Nakagawa, and K. Tomishige, "Reaction mechanism of the glycerol hydrogenolysis to 1,3-propanediol over $\mathrm{Ir}-\mathrm{ReO}_{x} / \mathrm{SiO}_{2}$ catalyst," Applied Catalysis B: Environmental, vol. 105, no. 1-2, pp. 117-127, 2011.

[44] Y.-C. Hsieh, L.-C. Chang, P.-W. Wu, Y.-M. Chang, and J.-F. Lee, "Displacement reaction of $\mathrm{Pt}$ on carbon-supported $\mathrm{Ru}$ nanoparticles in hexachloroplatinic acids," Applied Catalysis B: Environmental, vol. 103, no. 1-2, pp. 116-127, 2011. 
[45] S. Chotisuwan, J. Wittayakun, and B. C. Gates, "EXAFS characterization of supported $\mathrm{PtRu} / \mathrm{MgO}$ prepared from a molecular precursor and organometallic mixture," Studies in Surface Science and Catalysis, vol. 159, pp. 209-212, 2006.

[46] Y. Wang and N. Toshima, "Preparation of Pd-Pt bimetallic colloids with controllable core/shell structures," The Journal of Physical Chemistry B, vol. 101, no. 27, pp. 5301-5306, 1997.

[47] C. W. Hills, M. S. Nashner, A. I. Frenkel, J. R. Shapley, and R. G. Nuzzo, "Carbon support effects on bimetallic Pt-Ru nanoparticles formed from molecular precursors," Langmuir, vol. 15, no. 3, pp. 690-700, 1999.

[48] H. Bönnemann and R. M. Richards, "Nanoscopic metal particles-synthetic methods and potential applications," European Journal of Inorganic Chemistry, no. 10, pp. 2455-2480, 2001.

[49] R. W. J. Scott, O. M. Wilson, S.-K. Oh, E. A. Kenik, and R. M. Crooks, "Bimetallic palladium-gold dendrimer-encapsulated catalysts," Journal of the American Chemical Society, vol. 126, no. 47, pp. 15583-15591, 2004.

[50] S. Zhou, B. Varughese, B. Eichhorn, G. Jackson, and K. McIlwrath, "Pt-Cu core-shell and alloy nanoparticles for heterogeneous $\mathrm{NO}_{x}$ reduction: anomalous stability and reactivity of a core-shell nanostructure," Angewandte Chemie-International Edition, vol. 44, no. 29, pp. 4539-4543, 2005.

[51] R. L. Mieville, "Platinum-rhenium interaction: a temperatureprogrammed reduction study," Journal of Catalysis, vol. 87, no. 2, pp. 437-442, 1984.

[52] Y.-C. Wei, C.-W. Liu, and K.-W. Wang, "Activity-structure correlation of $\mathrm{Pt} / \mathrm{Ru}$ catalysts for the electrodecomposition of methanol: the importance of $\mathrm{RuO}_{2}$ and PtRu alloying," ChemPhysChem, vol. 10, no. 8, pp. 1230-1237, 2009.

[53] T. Page, R. Johnson, J. Hormes, S. Noding, and B. Rambabu, "Study of methanol electro-oxidation reactions in carbon membrane electrodes and structural properties of Pt alloy electrocatalysts by EXAFS," Journal of Electroanalytical Chemistry, vol. 485, no. 1, pp. 34-41, 2000.

[54] Y. Amada, H. Watanabe, M. Tamura, Y. Nakagawa, K. Okumura, and $\mathrm{K}$. Tomishige, "Structure of $\mathrm{ReO}_{x}$ clusters attached on the Ir metal surface in $\mathrm{Ir}-\mathrm{ReO}_{x} / \mathrm{SiO}_{2}$ for the hydrogenolysis reaction," The Journal of Physical Chemistry C, vol. 116, no. 44, pp. 2350323514, 2012.

[55] C. A. Jan, T. B. Lin, and J. R. Chang, "Aromatics reduction over supported platinum catalysts. 3. Effects of catalyst precursors and pretreatment conditions on the performance of palladiumpromoted platinum catalysts," Industrial \& Engineering Chemistry Research, vol. 35, no. 11, pp. 3893-3898, 1996.

[56] B. D. McNicol, "The reducibility of rhenium in re on $\gamma$-alumina and ptre on $\gamma$-alumina catalysts," Journal of Catalysis, vol. 46, no. 3, pp. 438-440, 1977.

[57] M. Vaarkamp, J. C. Linders, and D. C. Koningsberger, "A new method for parameterization of phase shift and backscattering amplitude," Physica B: Condensed Matter, vol. 208-209, pp. 159$160,1995$.

[58] M. Vaarkamp, I. Dring, R. J. Oldman, E. A. Stern, and D. C. Koningsberger, "Comparison of theoretical methods for the calculation of extended X-ray-absorption fine structure," Physical Review B, vol. 50, no. 11, pp. 7872-7883, 1994.

[59] J. W. Cook Jr. and D. E. Sayers, "Criteria for automatic Xray absorption fine structure background removal," Journal of Applied Physics, vol. 52, no. 8, pp. 5024-5031, 1981.
[60] J. B. A. D. van Zon, D. C. Koningsberger, H. F. J. van’t Blik, and D. E. Sayers, "An EXAFS study of the structure of the metalsupport interface in highly dispersed $\mathrm{Rh} / \mathrm{Al}_{2} \mathrm{O}_{3}$ catalysts," The Journal of Chemical Physics, vol. 82, no. 12, pp. 5742-5754, 1985.

[61] J. H. A. Martens, A spectroscopic characterization of the structure of supported metal catalysts [Ph.D. thesis], Technische Universiteit Eindhoven, 1988.

[62] S. I. Zabinsky, J. J. Rehr, A. Ankudinov, R. C. Albers, and M. J. Eller, "Multiple-scattering calculations of X-ray-absorption spectra," Physical Review B, vol. 52, no. 4, pp. 2995-3009, 1995.

[63] R. M. Jao, T. B. Lin, and J. R. Chang, "Light naphtha isomerization over mordenite-supported Ni-Pt catalysts: effects of $\mathrm{Ni}$ on the catalytic performance for pure feed and sulfur-containing feed," Journal of Catalysis, vol. 161, no. 1, pp. 222-229, 1996.

[64] C.-C. Shih and J.-R. Chang, "Pt/C stabilization for catalytic wetair oxidation: use of grafted $\mathrm{TiO}_{2}$," Journal of Catalysis, vol. 240, no. 2, pp. 137-150, 2006.

[65] D. C. Koningsberger and R. Prins, X-Ray Absorption: Principles, Applications, Techniques of EXAFS, SEXAFS and XANES, John Wiley \& Sons, New York, NY, USA, 1988.

[66] K. Asakura, in X-Ray AbsorptionFine Structure for Catalysts and Surface, Y. Iwasawa, Ed., World Scientific, Singapore, 1995.

[67] J. B. A. D. van Zon, [Ph.D. dissertation], Eindhoven University of Technology, Eindhoven, The Netherlands, 1988.

[68] M. Varrkamp, XDAP User's Guide, XAFS Services International, Utrecht, The Netherlands, 1996.

[69] A. S. Fung, M. R. Mcdevitt, P. A. Tooley, M. J. Kelley, D. C. Koningsberger, and B. C. Gates, "A model $\gamma-\mathrm{Al}_{2} \mathrm{O}_{3}$-supported $\mathrm{Re}-\mathrm{Pt}$ catalyst prepared from $\left[\operatorname{Re}_{2} \mathrm{Pt}(\mathrm{CO})_{12}\right]$. I. Synthesis and spectroscopic characterization," Journal of Catalysis, vol. 140, no. 1, pp. 190-208, 1993.

[70] C.-C. Shih and J.-R. Chang, "Genesis and growth of platinum subnano-particles on activated-carbon characterized by X-ray absorption spectroscopy: effects of preparation conditions," Materials Chemistry and Physics, vol. 92, no. 1, pp. 89-97, 2005.

[71] B. L. Mojet, J. T. Miller, D. E. Ramaker, and D. C. Koningsberger, "A new model describing the metal-support interaction in noble metal catalysts," Journal of Catalysis, vol. 186, no. 2, pp. 373-386, 1999.

[72] P. Malet, G. Munuera, and A. Caballero, "Effect of chlorine in the formation of PtRe alloys in $\mathrm{PtRe} \mathrm{Al}_{2} \mathrm{O}_{3}$ catalysts," Journal of Catalysis, vol. 115, no. 2, pp. 567-579, 1989.

[73] S. M. Augustine and W. M. H. Sachtler, "On the mechanism for the platinum-catalyzed reduction of rhenium in $\operatorname{PtRe} \gamma-\mathrm{Al}_{2} \mathrm{O}_{3}$," Journal of Catalysis, vol. 116, no. 1, pp. 184-194, 1989. 

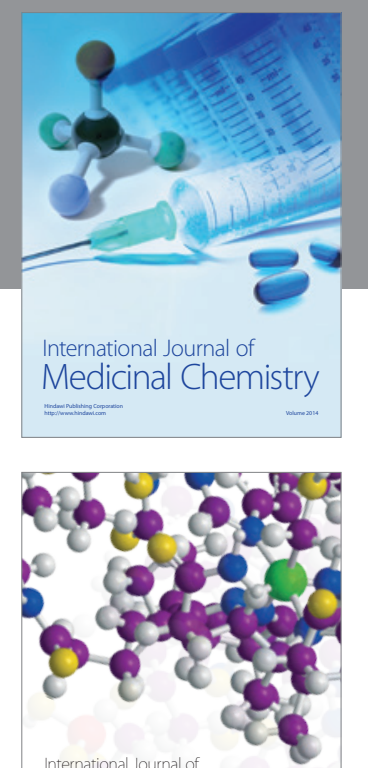

\section{Carbohydrate} Chemistry

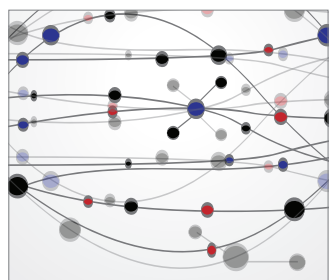

The Scientific World Journal
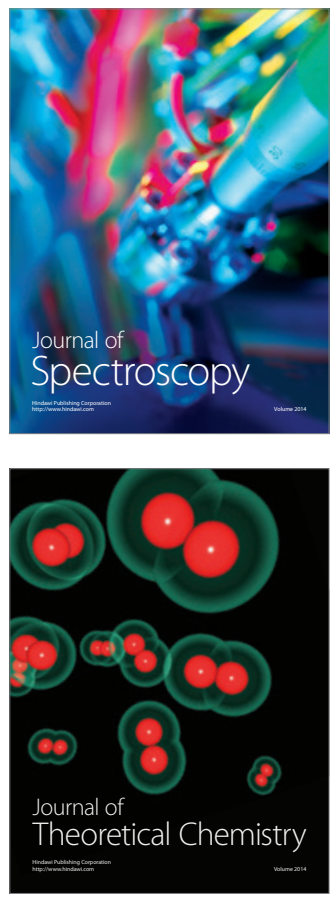
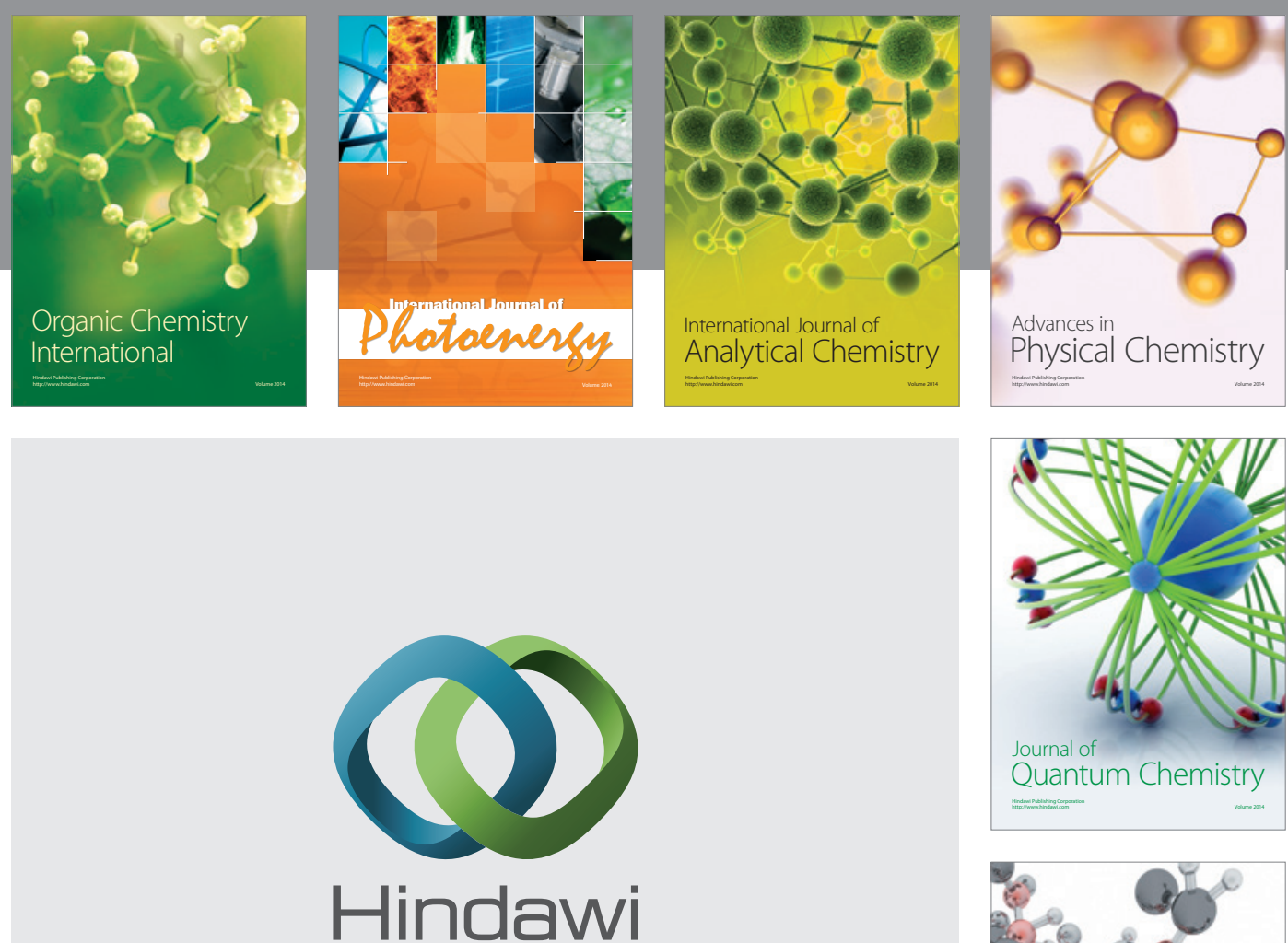

Submit your manuscripts at

http://www.hindawi.com

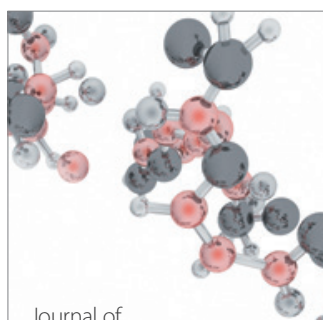

Analytical Methods

in Chemistry

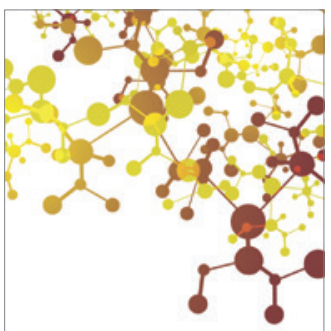

Journal of

Applied Chemistry

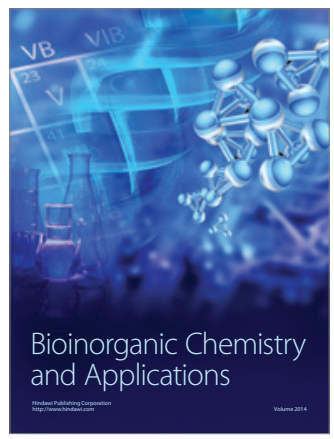

Inorganic Chemistry
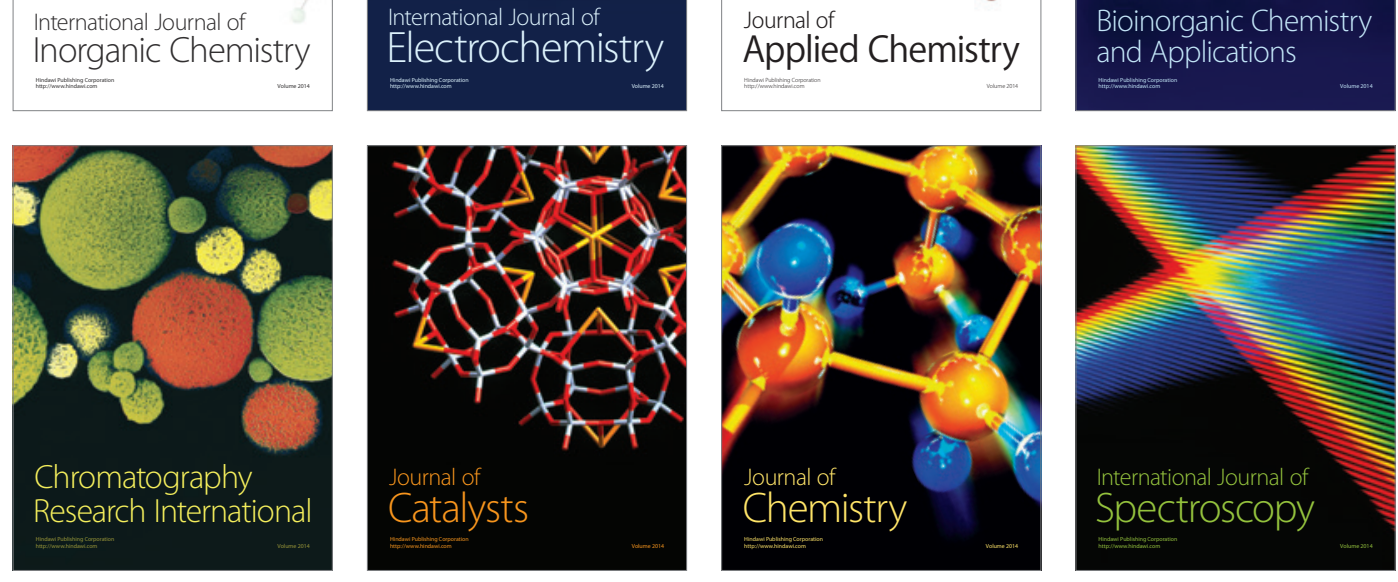